\title{
Serum Amyloid A Protein as a Potential Biomarker in predicting acute onset and association with in- hospital death in acute aortic dissection
}

\section{Yuchen He}

Chinese Academy of Medical Sciences and Peking Union Medical College

Changcheng Ma

Shengjing Hospital of China Medical University

Jia Xing

China Medical University

Shiyue Wang

the First Hospital of China Medical University

Ji Chao

Shengjing Hospital of China Medical University

Yanshuo Han ( $\nabla$ yanshuohan@cmu.edu.cn )

Shengjing Hospital of China Medical University https://orcid.org/0000-0002-4897-2998

Jian Zhang

the First Hospital of China Medical University

Research article

Keywords: Serum amyloid A; Acute aortic dissection; Biomarker; Inflammation

Posted Date: November 20th, 2019

DOI: https://doi.org/10.21203/rs.2.17288/v2

License: (c) (1) This work is licensed under a Creative Commons Attribution 4.0 International License.

Read Full License

Version of Record: A version of this preprint was published at BMC Cardiovascular Disorders on December 1st, 2019. See the published version at https://doi.org/10.1186/s12872-019-1267-0. 


\section{Abstract}

Background: Acute aortic dissection (AAD) is a life-threatening disorder in vascular surgery with a high early mortality. Serum amyloid $A(S A A)$ is a kind of acute-phase protein with a rapid diagnostic value in other diseases. However, the researches on the performance of SAA for the diagnosis of AAD is still lacking. This retrospective study aimed to evaluate the SAA levels and further explore its potential diagnostic role in AAD patients. Methods: SAA levels were measured by enzyme-linked immunosorbent assay (ELISA) in 63 controls and 87 AAD patients. Laboratory examinations were also performed. And relative clinical information was collected from participants included in this study. Results: SAA levels were significantly higher in AAD patients than those in healthy controls. SAA levels were independently associated with the risk of $A A D$. There was a positive significant correlation between SAA and $C$ reactive protein $(R=0.442$, and $P=0.001)$. Based on receiver-operating characteristic $(R O C)$ analysis, the area under the curve (AUC) of SAA for the diagnosis of AAD were 0.942 with optimal cut-off points of $0.427 \mathrm{mg} / \mathrm{L}$. For in-hospital mortality, the AUC of SAA were 0.732 with optimal cut-off points of $0.500 \mathrm{mg} / \mathrm{L}$. According to logistic regression analysis, higher SAA levels represent a higher risk of in-hospital mortality $(O R=1.25$; $95 \% \mathrm{Cl}: 1.07-1.47 ; \mathrm{P}=0.005)$. Conclusion: Our findings demonstrated that $\mathrm{SAA}$ levels were significantly enhanced in AAD. SAA was closely correlated with inflammatory parameters and coagulation-related parameters in AAD. Furthermore, SAA could be a potential bio-marker for identifying AAD in the early diagnosis. Finally, $S A A>5.0 \mathrm{mg} / \mathrm{L}$ are independently related to $A A D$ in-hospital mortality.

\section{Background}

Acute aortic dissection (AAD) is a life-threatening disorder in vascular surgery defined as the separation of aortic wall layer $(1,2)$. In line with the Stanford classification, AAD is commonly divided into type A aortic dissection (TAAD) (involving ascending aorta) as well as type $B$ aortic dissection (TBAD) (ascending aorta not affected) by considering both dissection extent and lesion site $(3,4)$.

$A A D$ is characterized by acute onset, rapid progression as well as high morbidity and mortality in early stage. It has been previously reported that approximately $48.6 \%$ of untreated AAD patients die prehospitally (5). Meanwhile, both TAAD and TBAD have high short-term in-hospital mortality. Medical imaging, including computed tomography (CT) and magnetic resonance imaging (MRI), is a reliable approach for AAD diagnosis $(2,6)$. However, due to the mimic clinical manifestations between AAD and other common disorders and the uncertain aorta site of AAD lesion, it is difficult to diagnose on initial evaluation. Therefore, it is critically necessary to make early and confirmed diagnosis for patients with AAD to prevent disease proceeding (7).

In addition, the clinical values of several serum biomarkers in the early diagnosis of $A A D$ are increasingly recognized $(8,9)$. For instance, $C$ reactive protein (CRP) and D-dimer have been included in the ESC guideline for aortic diseases for the assessment of AAD patient conditions (10-12). An ideal biomarker should be generally characterized by a rapid diagnostic value, a low cost, noninvasive and easy to perform with its potential sensitivity and specificity. 
Serum amyloid A (SAA), is a specific apolipoprotein of high-density lipoprotein cholesterol (HDL-C), involved in the acute phase response. Diverse functions of SAA have been proved in cardiovascular diseases (CVD), including regulating matrix metalloproteinase-2 activity in aorta (13), modifying the vascular functionality of HDL-C (14), and regulation of systemic inflammatory reaction (15). Recent research efforts have focused on the potential role of SAA as a biomarker in clinical disorders $(16,17)$. However, there has been no study concerning the value of SAA in the early diagnosis and prognostic prediction in AAD.

In this study, the levels of SAA were assessed in AAD subjects as well as normal controls, followed by analysis of the potential correlation of SAA with AAD. We also investigated the diagnostic performance of SAA as a novel clinical biomarker in AAD prediction. Moreover, we also aimed to analyze the association between SAA and these classical biomarkers, including CRP as well as D-dimer level, followed by analysis on the possible combined diagnostic efficacy to detect AAD. Finally, the possible correlations between AAD prognosis and SAA level were identified.

\section{Methods}

\section{Study population}

In this retrospective study, eligible aortic dissection patients were selected from two Affiliated Hospital of China Medical University (Shenyang, China). In brief, 131 consecutive AAD patients with corresponding peripheral blood samples and clinical data were collected from the Department of Vascular Surgery of the First Hospital of China Medical University (CMU) immediately after admission between May 2014 and February 2019. In addition, another 93 AAD patients were collected from the Department of Clinical Laboratory, Shengjing Hospital of CMU between January 2016 and January 2018. Among these 93 patients, 50 and 43 patients were diagnosed with TAAD and TBAD, respectively, during hospitalization (Figure 1). The diagnosis of AD was based on imaging outcomes (CT, MRI and echocardiography). The $A D$ was categorized in line with Stanford classification(18).

\section{Definitions}

AD could be divided into acute as well as chronic phases. AAD is diagnosed if a patient is admitted to hospitalization within 14 days of symptom onset, otherwise, chronic AD is considered (5). Moreover, acute AD patients admitted to the department of emergency of our two clinical centers were clearly diagnosed after careful assessment within $24 \mathrm{~h}$ following symptom onset. The diagnostic criteria of hypertension included a clinical record of systolic blood pressure (BP) $\geq 140 \mathrm{mmHg}$ and/or diastolic BP $\geq 90 \mathrm{mmHg}$, and the administration of anti-hypertensive drugs. The definition of diabetes mellitus (DM) included fasting glucose level $\geq 7.0 \mathrm{mmol} / \mathrm{L}$, glycosylated haemoglobin $\mathrm{A} 1 \mathrm{c} \geq 6.5 \%$ and the administration of oral hypoglycaemic drugs or insulin. In addition, the smoking status was judged in accordance with self-report current smokers. 
The definitions of terms utilized in this research were listed in the following. The definition of a communicating false lumen in $A A D$ is the opacification of at least partial false lumen with contrast media except ulcer-like projection (19). On the contrary, a non-communicating false lumen in AAD is defined by the completely occlusive false lumen by a thrombus, as well as ulcer-like projection. Moreover, the definition of upper and lower strata SAA levels were set in line with cut-off value of receiver operating curve (ROC), which was $0.427 \mu \mathrm{g} / \mathrm{mL}$ as cut-off value in the present study.

\section{Exclusion Criteria}

We really appreciate your kind recommendation. Corresponding modification has been made in revised version, as follows, "The AD patients with the following disorders were eliminated: chronic aortic dissection, malignancy, autoimmune disorders, severe aortic stenosis which was defined by an aortic valve area less than $1.0 \mathrm{~cm}^{2}$ or less than $0.6 \mathrm{~cm}^{2} / \mathrm{m}^{2}$ if indexed to body surface area (20), hematological disorders, infectious diseases, coronary artery disease which was defined as the presence of at least one $\geq 50 \%$ stenosis in a coronary artery $\geq 2.0 \mathrm{~mm}$ in diameter based on either coronary computed tomography angiography or invasive coronary angiography examination (21), severe organ failure, congenital heart disorders, previous aortic operation, Marfan syndrome, Ehlers-Danlos syndrome, other types of combined connective tissue or vascular disorders, and those receiving non-steroidal antiinflammatory drugs or steroids. These disorders were ruled out using angiographic diagnosis, imaging examinations, laboratory tests, echocardiography, and other medical examinations based on the clinical presentations and medical history of patients. Eventually, there were 55 from First Hospital and 28 from Shengjing Hospital incongruent patients eliminated in this study (Figure 1).

\section{Aortic Dissection blood sample Biobank}

After excluding incongruent participates, on February 2019, eight and twelve patients were unwillingly to provide their inpatient record for publication, including their clinical data or blood samples, respectively (Figure 1). Finally, aortic dissection blood samples from 68 patients were eligible for further analyses as Biobank, which registered in the First $\underline{H}$ ospital of CMU Aortic Dissection $\underline{B}$ lood sample Biobank $(1 \mathrm{H}-$ $A D B B / C M U$ ) were selected to identity AAD. As a result, a total of 53 blood samples from AAD patients registered in Shengjing Hospital of CMU Aortic Dissection Blood sample Biobank (SJH-ADBB/CMU) were eligible and further enrolled in this study.

Venipuncture was conducted on eligible patients after their admissions, followed by sample collection of in EDTA plastic tubes (BD Vacutainer ${ }^{\circledR}$ lavender, $5.0 \mathrm{~mL}$ ) and anticoagulant and silica/gel plastic tubes (SST BD Vacutainer ${ }^{\circledR}$ gold, $5.0 \mathrm{~mL}$ ). Moreover, blood sample was centrifuged to collect plasma, which was reserved at $-80^{\circ} \mathrm{C}$ for further test (up to 1 year). Peripheral blood mononuclear cells (PBMCs) of these $A D$ 
patients were extracted by Ficoll-sodium diatrizoate density gradient centrifugation as described previously(22).

The present AD Biobank research was conducted in line with the Guidelines of the World Medical Association Declaration of Helsinki, and was approved by the Ethics Committee of Shengjing Hospital (Ethics Approval No. 2016PS085K) of China Medical University. All 121 subjects signed written informed consent.

\section{Serum measurements}

ELISA kits (SAA: Wuhan Boster Biotechnology Company, China) were purchased to determine the SAA levels according to the manufacturer's protocol.

\section{Laboratory examinations}

Lipid panel. The plasma levels of low-density lipid cholesterol (LDL-C) and high-density lipid cholesterol (HDL-C) were directly detected using selective solubilization method (LDL-C test Kit or Determiner L HDL, Kyowa Medex, Tokyo). Additionally, levels of total cholesterol (TC) as well as TG were measured by enzymatic methods. Automatic biochemistry analyzer (ARCHIRECT ci16200, Abbott Laboratories, USA) was utilized to produce lipid profiles.

Additional biochemistry. Alanine aminotransferase (ALT) and glutamic oxalacetic transaminase (AST) were determined utilizing International Federation of Clinical Chemistry approach (Abbott Laboratories, USA). The plasma concentration of total protein (TP) was determined using biuret method (FUJIFILM Wako Pure Chemical industries Ltd, Japan). The fasting plasma glucose (FPG) levels were determined by urease GLDH and glucose oxidase methods (DiaSys Diagnostic Systems GmbH, Germany).

D-Dimer and CRP. Immunoturbidimetry was used to assess plasma D-dimer levels (Diagnostica Stago, France, normal limit $\leq 0.5 \mu \mathrm{g} / \mathrm{mL}$ ). High-sensitivity assay with BN II nephelometer (Dade Behring, Germany) was used to detect CRP levels (normal limit $\leq 0.17 \mathrm{mg} / \mathrm{L}$ ).

All blood analyses were carried out by Department of Clinical Laboratory at CMU Shengjing Hospital and Department of Clinical Laboratory of First Hospital of China Medical University for SJH-AADBB/CMU Biobank and 1H-AADBB/CMU Biobank, respectively. Follow by clinical data collection, blood Biobank establishment, and laboratory examinations, total of 87 eligible participates (TAAD $=37$ and TBAD $=50)$ were finally identified to meet the inclusion criteria. A summary of the flow of participants' selection and inclusion process is illustrated in Figure 1. 


\section{Control Group (Ctrl)}

The blood sample from 87 patients with AAD were available from the venipuncture together with the blood samples from 63 matched controls. Shengjing Hospital of China Medical University Hospital medical examination database was used to identify healthy control by thoroughly searching all patients admitted to the emergency department diagnosed with trauma or motor vehicle accident during the 20142018 period (with imaging examinations, CT and/or MRI, at admission). All participants that were hemodynamicly stable and had non-typical symptoms, were considered as candidates of the control group. The control group was selected because these patients would not be expected to present any inherent bias favoring AAD. We also selected 20 matched patients diagnosed with stable angina as another control group. Stable angina was defined to chest discomfort that is classically retrosternal, triggered by exertion, and relieved by rest or nitrates within minutes (23). Subjects diagnosed with vascular or connective tissue disorders using imaging examinations, CT and/or MRI, at admission were excluded from the control group. Other exclusion criteria included malignancy, infection, drug history, or any other immune-related disorders. Eventually, 63 participants in the control group and 20 patients in the angina group were included in this study. And all 83 subjects as control also signed written informed consent and conducted in line with the Guidelines of the World Medical Association Declaration of Helsinki.

\section{Statistical analysis}

SPSS 22.0 (SPSS Inc., Chicago, IL, USA) was utilized for statistical analysis. Data were shown as medians with upper or lower quartiles for continuous variables due to the non-Gaussian data distribution. The difference between two groups was measured by non-parametric Mann-Whitney test, respectively. Comparisons among three groups were performed by one-way ANOVA, followed by Tukey's post-hoc test, or nonparametric tests, followed by Kruskal-Wallis 1-way ANOVA test, according to the normality of the values. Categorical variables were shown as numbers with percentages, and the differences between two groups (for both biochemical and clinical parameters) was determined by Chi-square test. Correlations between continuous variables were analyzed through partial correlation analysis accounting for age, gender, and smoking. Furthermore, multiple logistic regression analysis was conducted to evaluate the correlation of serum SAA and D-Dimer or CRP with AAD risk following the adjustment of possible confounding factors. For instance, demographic characteristics and comorbidities were adjusted as confounding factors in all multivariable logistic regression models. Receiver operator characteristic (ROC) curves with area under the curve (AUC) along with logistic models were employed to determine the corresponding cut-off points and to assess the diagnostic performance of serum SAA and D-Dimer or CRP individually, and combined for AAD detection. P values $<0.05$ were considered as statistical significance.

\section{Results}




\section{Basic clinical characteristics of patients}

The detailed clinical features of all subjects were shown in Table 1. Patients had significantly higher levels of heart rate, higher ratio of hypertension and smoker, higher white blood cell (WBC), platelet (PLT), and fast plasma glucose (FPG) $(P<0.001, P=0.001, P=0.048, P<0.001, P=0.033$ and $P<0.001$ respectively), but lower level of hemoglobin $(\mathrm{Hb})$ in overall $A A D$, type $A$ and type $B$ groups in comparison to the control group $(P<0.001)$. Additionally, TAAD was not significantly different from TBAD in other comparisons. Nevertheless, these features were not statistically different between TAAD group and TBAD group. Moreover, in terms of other clinical features, including age, gender, BMI and rate of diabetes mellitus, healthy controls were not significantly different from AAD groups. Expectedly, the level of SAA protein was significantly enhanced in AAD group in comparison to the healthy control group (AAD vs Ctrl, $P<0.001$; TAAD vs Ctrl, $P<0.001$; TBAD vs Ctrl, $P<0.001$; Table 1 and Figure 2A). The SAA level was not significantly different between TAAD group and TBAD group ( $P=0.595$; Table 1 and Figure 2A).

Additionally, we compared SAA levels between control subjects and AAD, angina patients and AAD patients stratified by cardiovascular risk factors (Table 2). SAA levels of AAD patients significantly elevated, compared with the control group and angina patients in each stratified analysis.

Sub-group analysis of AAD patient group was summarized in Table 3, without any significant differences between high-risk pain features that persisted less than six hours and more than six hours $(P=0.583$;

Figure 2B). Additionally, there was no significant differences between and communicating and noncommunicating false lumen ( $C$ and $N C$ ) for these clinical characteristics $(P=0.416$; Figure 2C). Thus, both survival and death cases were enrolled in the study subjects. As a result, WBC count (12.78 \pm 4.05 vs 9.96 $\left.\pm 4.08 \times 10^{9} / \mathrm{L}, \mathrm{P}=0.004\right)$, percent of neutrophil (77.88 \pm 10.9 vs $\left.70.15 \pm 14.72, \mathrm{P}=0.017\right)$, lactate dehydrogenase ( $826.64 \pm 1148.14$ vs $359 \pm 255.33, P=0.036), F P G(7.90 \pm 2.25$ vs $6.92 \pm 2.46 \mathrm{mmol} / \mathrm{L}$, $\mathrm{P}=0.032)$, plasma $\mathrm{D}$-dimer $(6.20 \pm 6.91$ vs $1.83 \pm 3.05 \mu \mathrm{g} / \mathrm{mL}, \mathrm{P}=0.006)$, CRP (138.21 \pm 68.8 vs $48.78 \pm$ $50.86 \mathrm{mg} / \mathrm{L}, \mathrm{P}<0.001)$ concentrations and SAA $(6.214 \pm 0.651 \mathrm{vs} 3.783 \pm 0.314 \mu \mathrm{g} / \mathrm{mL}, \mathrm{P}=0.001)$ were significantly increased in death cases compared to those in survival cases (Figure 2D).

\section{Association of SAA levels with clinical features}

The correlation of SAA levels with clinical features was assessed in AAD subjects. As a result, SAA levels were positively correlated with heart rate $(R=0.333$, and $P=0.001$; Figure $3 A), F P G$ level $(R=0.654$, and $P<0.001$; Figure 3B), $W B C$ count $(R=0.257$, and $P=0.042$; Figure $3 C)$, lactate dehydrogenase $(R=0.357$, $P=0.006)$, neutrophil count $(R=0.257, P=0.025)$, Cystatin $C$ level (CYSC, $R=0.248, P=0.046)$ and plasma CRP concentration ( $R=0.442$, and $P=0.001$; Figure 3D). Correlations between SAA and other clinical characteristics were shown in Table 4. 


\section{Diagnostic performance of SAA, CRP and their combination for AAD}

ROC analysis was conducted to determine the cut-off value of SAA level for the evaluation of TAAD, TBAD, and AAD. The AUCs for TAAD, TBAD, and AAD alone were $0.939,0.937$ and 0.942 with optimal cutoff points of $0.427 \mu \mathrm{g} / \mathrm{mL}, 0.462 \mu \mathrm{g} / \mathrm{mL}$, and $0.427 \mu \mathrm{g} / \mathrm{mL}$, respectively, associated with sensitivity of $91.9 \%, 88.1 \%$ and $90.8 \%$, respectively, and specificity of $93.7 \%, 93.7 \%$ and $93.7 \%$, respectively (Table 5 and Figure 4). Furthermore, the diagnostic performance of SAA, CRP and their combination to discriminate AAD according to ROC analysis, were also shown in Table 5. The AUC (0.977) of combined model (SAA+CRP) was significantly greater than that of SAA (AUC, 0.942), but not combined model (SAA+D-dimer, AUC $=0.900$ ). Furthermore, SAA+CRP yielded sensitivity of $94.4 \%$ and specificity of $93.8 \%$. ROC analysis was subsequently conducted to examine the cut-off values of SAA and other prognostic biomarkers for evaluation of in-hospital mortality (Table 5). The cut-off values were $4.998 \mu \mathrm{g} / \mathrm{mL}$ for SAA, $82.55 \mathrm{mg} / \mathrm{L}$ for CRP, $1.945 \mu \mathrm{g} / \mathrm{mL}$ for D-dimer, and $72.976 \%$ for neutrophil to lymphocyte ratio (NE\%) with their higher sensitivity and specificity, respectively. The AUCs were 0.732 for SAA, 0.826 for CRP, 0.715 for D-dimer and 0.678 for NE\%, respectively. In the case of SAA $\geq 4.998 \mu \mathrm{g} / \mathrm{mL}$, the sensitivity and specificity for in-hospital mortality prediction were $73.9 \%$ and $62.5 \%(95 \% \mathrm{Cl} 0.61$ to $0.85 ; \mathrm{P}=0.001)$ for AAD patients. When CRP was $\geq 82.55 \mathrm{mg} / \mathrm{L}$, the sensitivity and specificity were 0.789 and 0.771 ( $95 \% \mathrm{Cl} 0.709$ to 0.942 ; $\mathrm{p}<0.001)$. When $\mathrm{D}$-dimer was $\geq 1.945 \mu \mathrm{g} / \mathrm{mL}$, the sensitivity and specificity in predicting in-hospital death were 0.700 and 0.739 ( $95 \% \mathrm{Cl} 0.562$ to $0.869 ; \mathrm{p}=0.006$ ). When $\mathrm{NE} \%$ was $\geq 72.976 \%$, the sensitivity and specificity in predicting in-hospital death were 0.857 and 0.491 ( $95 \% \mathrm{Cl} 0.549$ to $0.808 ; \mathrm{p}=0.017$ ).

\section{The stratum of SAA according to gender and clinical biomarkers}

The upper and lower strata of SAA levels were defined according to the cut-off values for the ROC, which in the present study were $0.427 \mu \mathrm{g} / \mathrm{mL}$ for AAD patients. The prevalence of upper-stratum SAA levels was (78/87) 89.7\% in AAD patients, 87.7\% (57/65) in the male AAD group, and 95.5\% (21/22) in the female AAD group. There were no significant gender differences of prevalence of upper stratum SAA levels $(P=0.438)$. Moreover, a multiple logistic regression analysis revealed that the plasma CRP, WBC, neutrophil, and HDL-C levels were positively associated with the upper stratum of SAA levels when compared with the lower stratum $(\mathrm{OR}=1.05,1.74,1.97,1.06$, respectively, all P-values<0.05). Furthermore, plasma pre-albumin and lymphocyte levels showed negative associations with the upper stratum of the SAA levels when compared with the lower stratum (Table 6).

\section{Univariate and multivariate logistic regression analyses for in-hospital mortality}

The following ten variables were indicated to be related with hospital short-term mortality, WBC, eosinophils, lymphocyte, neutrophil, $\mathrm{HCO}_{3}$ level, lactate dehydrogenase, FPG, CRP, D-Dimer, and SAA concentration ( $P$ value was approximately 0.05 in univariate analysis) (Table 3). Therefore, the ten 
variables were incorporated into multivariate logistic regression analysis, revealing that $S A A(O R=1.25$; 95\%Cl: 1.07-1.47; $P=0.005), \mathrm{CRP}(\mathrm{OR}=1.03 ; 95 \% \mathrm{Cl}=1.01-1.104 ; \mathrm{P}<0.001)$, WBC count $(\mathrm{OR}=1.17 ; 95 \% \mathrm{Cl}$ : 1.03-1.33; $P=0.015)$ and eosinophils $(O R=1.06 ; 95 \% \mathrm{Cl}: 1.00-1.11 ; \mathrm{P}=0.041)$ were significantly related to hospital short-term mortality (Table 7) adjusted as confounding factors. Nevertheless, in-hospital death was not significantly associated with any of variables enrolled in this research.

\section{Discussion}

AAD is a severe aortic disorder associated with inflammation $(8,15,24)$. The inflammatory responses play a critical role in initiating further necrosis and apoptosis of smooth muscle cells as well as degeneration of elastic tissue, contributing to aorta rupture. SAA, an acute-phase protein, reflects the status of inflammation (25). The early diagnostic value of SAA as a serum biomarker has been increasingly recognized in other diseases. To our knowledge, it was first study to focus on the association between SAA and AAD, which demonstrated SAA as a potentially useful biomarker for AAD detection.

In this study, SAA levels were significantly higher in AAD patients than healthy controls. However, SAA levels were not significantly different between TAAD and TBAD, indicating that SAA was not associated with the specific subtype of AAD. Moreover, SAA was correlated with several laboratory examination outcomes, which were necessary to evaluate the status and to detect complications. According to the correlation analysis, SAA levels were significantly correlated with inflammation-related parameters, including WBC count, neutrophil to lymphocyte ratio and CRP. CRP, an acute phase reactant, has been widely used as an independent predictor of poor prognosis in AAD patients, which is also related to the inhospital mortality in AAD patients (12). Additionally, SAA was also correlated with APTT, INR and D-dimer in this study. AAD is widely known to be influenced by activated coagulation and fibrinolytic systems (26, 27). Among these, D-dimer shows its important diagnostic and prognostic value in AAD patients (9). However, SAA is not correlated with myocardial biomarkers in this study. The closely correlation between SAA and admission hematological parameters indicates the potential clinical significance of SAA in the clinical process of AAD.

Additionally, based on the elevated SAA levels in AAD patients, the diagnostic value of SAA alone and its combination with CRP as well as D-dimer was assessed for AAD detection. As a result, SAA was able provide high sensitivity and specificity for TAAD diagnosis by referring to the ROC curves. However, our data revealed high specificity but relatively weak sensitivity of SAA when used alone for TBAD.

Interestingly, compared with SAA alone, CRP-SAA combination led to improved diagnostic accuracy along with the increased sensitivity as well as higher AUC, while D-Dimer-SAA combination failed to show the significant elevation of AUC. Taken together, these findings indicated that SAA may be a potential noninvasive predictor of $A A D$, especially for $A A D$ patients with normal CRP value.

Furthermore, SAA has been identified as an apolipoprotein of high-density lipoprotein cholesterol (HDL-C). Previous studies have indicated that HDL-C is negatively associated with cardiovascular risks, and low HDL-C levels may represent a high in-hospital mortality in AAD patients (28). SAA-HDL complex in blood 
has been demonstrated to have a high affinity for macrophages (14) and to further eliminate them from the blood in patients with sarcoidosis (29). Thus, increased SAA levels in AAD patients may be caused in response to the systemic inflammation, showing its potential value in predicting AAD characteristics. Additionally, on the one hand, the progressive degradation of extracellular matrix is also considered as a critical pathological feature in the pathogenesis and progression of AAD (30). On the other hand, SAA has been reported to elicit several kinds of matrix metalloproteinases induction in vascular smooth muscle cells in vitro $(15,31,32)$. Thus, elevated SAA level in AAD is of great significance for the evaluation of AAD development. In this study, AAD patients with low SAA levels are more likely to control disease status than those with high SAA levels. Collectively, these outcomes suggest the potential prognostic value of SAA in the clinical procedure of AAD.

In this study, we observe that high SAA levels are associated with high in-hospital mortality. It has been previously reported that high SAA levels were associated with mortality in other diseases. For example, higher SAA concentration was associated with all-cause mortality in patients with end-stage renal disease (33). Additionally, as an apolipoprotein of HDL, SAA can transforms HDL from a protective lipoprotein into a pro-atherosclerotic lipoprotein, which contributed to the substantially worsened cardiovascular outcome, which have been reported previously (34). Our results suggest that SAA levels in AAA patients may be a critical marker of all-cause mortality in AAD. Additionally, it has been reported previously that CRP, D-Dimer (12) and NE\% (35) are important risk factors for in-hospital mortality in AAD. In our study, we observed that CRP with AUC of 0.826 , the highest sensitivity and specificity, is the best prognostic indicator of the mortality, and the AUC of SAA in predicting in-hospital mortality $(A U C=0.732)$ is better than that of D-Dimer (AUC=0.715) and NE\% (AUC=0.678). Therefore, our result revealed the potential value of SAA as a prognostic biomarker of the in-hospital mortality in AAD.

However, there are some limitations in this study. To begin with, the population size was relatively small. Secondly, the specific study population was collected from only two clinical centers. Additionally, the detailed backgrounds of healthy controls were not clearly defined due to the incomplete recording of their previous medical history. Furthermore, a combination of tissue expression and mechanism study would definitely give rise to more detailed information concerning the role of SAA in AAD.

\section{Conclusions}

Collectively, our findings demonstrated that SAA levels were significantly enhanced in both TAAD as well as TBAD patients. Then, we suggested the close correlations of SAA with inflammatory parameters and coagulation-related parameters in AAD patients at the level of serology. Furthermore, we provided the proof that SAA may be a useful biomarker for $A A D$ identification, and $S A A>5.0 \mathrm{mg} / \mathrm{L}$ is considered as important risk factors, which are independently related to AAD in-hospital mortality. Nevertheless, prospective, large-scale clinical studies are warranted to further validate these outcomes, which would definitely contribute to the prognostic evaluation of AAD.

\section{Abbreviations}


AAD: Acute aortic dissection; ALT: Alanine aminotransferase; AST: Glutamic oxalacetic transaminase;

AUC: The area under the curve; BP: Blood pressure; CMU: China Medical University; CRP: C-reactive protein; CT: Computed tomography; Ctrl: Control group; CVD: Cardiovascular diseases; CYSC: Cystatin C level; $C$ and NC: Communicating and non-communicating false lumen; DM: Diabetes mellitus; FPG: Fasting plasma glucose; HDL-C: High-density lipoprotein cholesterol; LDL-C: Low-density lipid cholesterol; MRI: Magnetic resonance imaging; NE\%: Neutrophil to lymphocyte ratio; PBMCs: Peripheral blood mononuclear cells; ROC: Receiver-operating characteristic; SAA: Serum amyloid A; SJH-ADBB/CMU: Shengjing Hospital of CMU Aortic Dissection Blood sample Biobank; TAAD: Type A aortic dissection; TBAD: Type B aortic dissection; TP: Total protein; WBC: White blood cell; 1H-ADBB/CMU: the First Hospital of CMU Aortic Dissection Blood sample Biobank.

\section{Declarations}

\section{Ethics approval and consent to participate}

Participants gave written informed consent before the study, and the study protocol was approved by the Ethics Committee of China Medical University (CMU), in accordance with the Declaration of Helsinki.

\section{Consent for publication}

All the participants provided written informed consent for the publication of the results of this study.

\section{Availability of data and materials}

The data used in this study are available from the corresponding author if needed.

\section{Competing interests:}

The authors declare that they have no conflict interests.

\section{Funding}

This work was supported by National Natural Science Foundation of China (grant number: 81600370), China Postdoctoral Science Foundation (grant number: 2018M640270) and Liaoning Provincial Natural Science Foundation of China (2019-ZD-0789) to Yanshuo Han, and National Natural Science Foundation of China (grant number: 81970402) and basic research program of Liaoning provincial institutions of higher learning 2017 (LZDK201701) to Jian Zhang. They funded the expenses of laboratory tests, the collection of data, preparation of the manuscript and a revision of the written English.

\section{Author Contributions}

$\mathrm{YCH}$ and JX performed the experimental work. $\mathrm{YSH}$ and $\mathrm{YCH}$ analyzed the results and composed the manuscript. SYW, CCM, CJ and YCH participated in the collection of clinical data. JZ, and YSH designed the study and participated in editing the manuscript. All authors read and approved the final manuscript. 


\section{Acknowledgments}

We thank Dr. Shihan Zhen for editing the English text of a draft of the manuscript.

\section{References}

1. Hiratzka LF, Bakris GL, Beckman JA, Bersin RM, Carr VF, Casey DE, Jr., et al. 2010 ACCF/AHA/AATS/ACR/ASA/SCA/SCAI/SIR/STS/SVM guidelines for the diagnosis and management of patients with Thoracic Aortic Disease: a report of the American College of Cardiology Foundation/American Heart Association Task Force on Practice Guidelines, American Association for Thoracic Surgery, American College of Radiology, American Stroke Association, Society of Cardiovascular Anesthesiologists, Society for Cardiovascular Angiography and Interventions, Society of Interventional Radiology, Society of Thoracic Surgeons, and Society for Vascular Medicine. Circulation. 2010;121(13):e266-369.

2. Hiratzka LF, Bakris GL, Beckman JA, Bersin RM, Carr VF, Casey DE, Jr., et al. 2010 ACCF/AHA/AATS/ACR/ASA/SCA/SCAI/SIR/STS/SVM guidelines for the diagnosis and management of patients with thoracic aortic disease: executive summary. A report of the American College of Cardiology Foundation/American Heart Association Task Force on Practice Guidelines, American Association for Thoracic Surgery, American College of Radiology, American Stroke Association, Society of Cardiovascular Anesthesiologists, Society for Cardiovascular Angiography and Interventions, Society of Interventional Radiology, Society of Thoracic Surgeons, and Society for Vascular Medicine. Catheter Cardiovasc Interv. 2010;76(2):E43-86.

3. Hughes GC, Andersen ND, McCann RL. Management of acute type B aortic dissection. J Thorac Cardiovasc Surg. 2013;145(3 Suppl):S202-7.

4. Shen S, Zhang J, Han Y, Lun Y, Wu X, Jiang H, et al. [Comparative study in clinical features and managements of aortic dissection between Chinese and Caucasians]. Zhonghua Yi Xue Za Zhi. 2015;95(10):776-80.

5. Hagan PG, Nienaber CA, Isselbacher EM, Bruckman D, Karavite DJ, Russman PL, et al. The International Registry of Acute Aortic Dissection (IRAD): new insights into an old disease. JAMA. 2000;283(7):897-903.

6. Erbel R, Aboyans V, Boileau C, Bossone E, Bartolomeo RD, Eggebrecht H, et al. 2014 ESC Guidelines on the diagnosis and treatment of aortic diseases: Document covering acute and chronic aortic diseases of the thoracic and abdominal aorta of the adult. The Task Force for the Diagnosis and Treatment of Aortic Diseases of the European Society of Cardiology (ESC). Eur Heart J. 2014;35(41):2873-926.

7. Klompas M. Does this patient have an acute thoracic aortic dissection? JAMA. 2002;287(17):226272.

8. McDermott MM, Liu K, Green D, Greenland P, Tian L, Kibbe M, et al. Changes in D-dimer and inflammatory biomarkers before ischemic events in patients with peripheral artery disease: The 
BRAVO Study. Vasc Med. 2016;21(1):12-20.

9. Nazerian P, Mueller C, Soeiro AM, Leidel BA, Salvadeo SAT, Giachino F, et al. Diagnostic Accuracy of the Aortic Dissection Detection Risk Score Plus D-Dimer for Acute Aortic Syndromes: The ADvISED Prospective Multicenter Study. Circulation. 2018;137(3):250-8.

10. Mori K, Tamune H, Tanaka H, Nakamura M. Admission Values of D-dimer and C-reactive Protein (CRP) Predict the Long-term Outcomes in Acute Aortic Dissection. Intern Med. 2016;55(14):1837-43.

11. Li T, Jing JJ, Yang J, Sun LP, Gong YH, Xin SJ, et al. Serum levels of matrix metalloproteinase 9 and toll-like receptor 4 in acute aortic dissection: a case-control study. BMC Cardiovasc Disord. 2018;18(1):219.

12. Wen D, Du X, Dong JZ, Zhou XL, Ma CS. Value of D-dimer and C reactive protein in predicting inhospital death in acute aortic dissection. Heart. 2013;99(16):1192-7.

13. Webb NR, De Beer MC, Wroblewski JM, Ji A, Bailey W, Shridas P, et al. Deficiency of Endogenous Acute-Phase Serum Amyloid A Protects apoE-/- Mice From Angiotensin II-Induced Abdominal Aortic Aneurysm Formation. Arterioscler Thromb Vasc Biol. 2015;35(5):1156-65.

14. Zhu S, Wang Y, Chen W, Li W, Wang A, Wong S, et al. High-Density Lipoprotein (HDL) CounterRegulates Serum Amyloid A (SAA)-Induced sPLA2-IIE and SPLA2-V Expression in Macrophages. PLoS One. 2016;11(11):e0167468.

15. O'Neill L, Rooney P, Molloy D, Connolly M, McCormick J, McCarthy G, et al. Regulation of Inflammation and Angiogenesis in Giant Cell Arteritis by Acute-Phase Serum Amyloid A. Arthritis Rheumatol. 2015;67(9):2447-56.

16. Yarur AJ, Quintero MA, Jain A, Czul F, Barkin JS, Abreu MT. Serum Amyloid A as a Surrogate Marker for Mucosal and Histologic Inflammation in Patients with Crohn's Disease. Inflamm Bowel Dis. 2017;23(1):158-64.

17. Vietri L, Bennett D, Cameli P, Bergantini L, Cillis G, Sestini P, et al. Serum amyloid A in patients with idiopathic pulmonary fibrosis. Respir Investig. 2019;57(5):430-4.

18. Nienaber CA, Eagle KA. Aortic dissection: new frontiers in diagnosis and management: Part I: from etiology to diagnostic strategies. Circulation. 2003;108(5):628-35.

19. Akutsu K, Yoshino H, Tobaru T, Hagiya K, Watanabe Y, Tanaka K, et al. Acute type B aortic dissection with communicating vs. non-communicating false lumen. Circ J. 2015;79(3):567-73.

20. Lanz J, Kim WK, Walther T, Burgdorf C, Mollmann H, Linke A, et al. Safety and efficacy of a selfexpanding versus a balloon-expandable bioprosthesis for transcatheter aortic valve replacement in patients with symptomatic severe aortic stenosis: a randomised non-inferiority trial. Lancet. 2019.

21. Rudzinski PN, Kruk M, Kepka C, Schoepf UJ, Duguay T, Dzielinska Z, et al. The value of Coronary Artery computed Tomography as the first-line anatomical test for stable patients with indications for invasive angiography due to suspected Coronary Artery Disease: CAT-CAD randomized trial. J Cardiovasc Comput Tomogr. 2018;12(6):472-9.

22. Tang D HY, Lun Y, Jiang H, Xin S, Duan Z, Zhang J Y chromosome loss is associated with age-related male patients with abdominal aortic aneurysms. Clinical Interventions in Aging. 2019;14:1227-41. 
23. Al-Lamee R, Davies J, Malik IS. What is the role of coronary angioplasty and stenting in stable angina? BMJ. 2016;352:i205.

24. Liu C, Zhang C, Jia L, Chen B, Liu L, Sun J, et al. Interleukin-3 stimulates matrix metalloproteinase 12 production from macrophages promoting thoracic aortic aneurysm/dissection. Clin Sci (Lond). 2018;132(6):655-68.

25. Cheng N, Liang Y, Du X, Ye RD. Serum amyloid A promotes LPS clearance and suppresses LPSinduced inflammation and tissue injury. EMBO Rep. 2018;19(10).

26. Li J, Guan X, Liu O, Wang X, Liu Y, Li H, et al. Changes in coagulation factor XII and its function during aortic arch surgery for acute aortic dissection-a prospective observational study. J Thorac Dis. 2018;10(7):4006-16.

27. Safiri S, Ayubi E. Comments on the relationship between fibrinogen and in-hospital mortality in patients with type A acute aortic dissection. Am J Emerg Med. 2018;36(7):1319.

28. Liu XT, He XW, Tan R, Liu WJ, Wang B, Liu YJ, et al. High-density lipoprotein cholesterol and inhospital mortality in patients with acute aortic dissection. J Huazhong Univ Sci Technolog Med Sci. 2016;36(3):364-7.

29. Jumeau C, Awad F, Assrawi E, Cobret L, Duquesnoy P, Giurgea I, et al. Expression of SAA1, SAA2 and SAA4 genes in human primary monocytes and monocyte-derived macrophages. PLoS One. 2019;14(5):e0217005.

30. Zhang L, Wang C, Xi Z, Li D, Xu Z. Mercaptoethanol Protects the Aorta from Dissection by Inhibiting Oxidative Stress, Inflammation, and Extracellular Matrix Degeneration in a Mouse Model. Med Sci Monit. 2018;24:1802-12.

31. Ghasemi S, Sardari K, Mirshokraei P, Hassanpour H. In vitro study of matrix metalloproteinases 1, 2, 9,13 and serum amyloid A mRNAs expression in equine fibroblast-like synoviocytes treated with doxycycline. Can J Vet Res. 2018;82(2):82-8.

32. Seidl SE, Pessolano LG, Jr., Bishop CA, Best M, Rich CB, Stone PJ, et al. Toll-like receptor 2 activation and serum amyloid $A$ regulate smooth muscle cell extracellular matrix. PLoS One. 2017;12(3):e0171711.

33. Saulnier PJ, Dieter BP, Tanamas SK, McPherson SM, Wheelock KM, Knowler WC, et al. Association of Serum Amyloid A with Kidney Outcomes and All-Cause Mortality in American Indians with Type 2 Diabetes. Am J Nephrol. 2017;46(4):276-84.

34. Zewinger S, Drechsler C, Kleber ME, Dressel A, Riffel J, Triem S, et al. Serum amyloid A: high-density lipoproteins interaction and cardiovascular risk. Eur Heart J. 2015;36(43):3007-16.

35. Onuk T, Gungor B, Karatas B, Ipek G, Akyuz S, Ozcan KS, et al. Increased Neutrophil to Lymphocyte Ratio is Associated with In-Hospital Mortality in Patients with Aortic Dissection. Clin Lab. 2015;61(9):1275-82.

\section{Tables}


Table 1 Demographic and laboratory parameters of participants included in this study

\begin{tabular}{|c|c|c|c|c|c|}
\hline & $\begin{array}{l}\text { Control } \\
(n=63)\end{array}$ & $\begin{array}{l}\text { Angina } \\
(n=20)\end{array}$ & $\mathrm{AAD}(\mathrm{n}=87)$ & P-value & $\begin{array}{l}\text { TAAD } \\
(\mathrm{n}=37)\end{array}$ \\
\hline & & & & $\begin{array}{l}\text { AAD vs } \\
\text { Control }\end{array}$ & \\
\hline & & & & $\begin{array}{l}\text { AAD vs } \\
\text { Angina }\end{array}$ & \\
\hline Male & $43(68.25 \%)$ & $15(75.00 \%)$ & $65(74.71 \%)$ & 0.657 & 27 (72.97\%) \\
\hline Hypertension & $21(33.33 \%)$ & $8(40.00 \%)$ & $54(62.69 \%)$ & $0.002 *$ & 27 (72.97\%) \\
\hline Smoking & 19 (30.16\%) & $7(35.00 \%)$ & $31(35.63)$ & 0.774 & 12 (32.43\%) \\
\hline $\mathrm{DM}$ & $10(15.87 \%)$ & $6(30.00 \%)$ & $26(29.89 \%)$ & 0.123 & $11(29.73 \%)$ \\
\hline Age & $\begin{array}{l}53.44 \pm \\
11.52\end{array}$ & $57.80 \pm 2.11$ & $\begin{array}{l}53.87 \pm \\
11.42\end{array}$ & 0.957 & $\begin{array}{l}53.32 \pm \\
11.12\end{array}$ \\
\hline BMI & $21.8 \pm 3.68$ & $23.70 \pm 0.73$ & $22.87 \pm 5.14$ & $\begin{array}{l}0.355 \\
0.357\end{array}$ & $22.24 \pm 3.92$ \\
\hline HR & $78.06 \pm 9.6$ & $79.45 \pm 1.68$ & $\begin{array}{l}89.46 \pm \\
12.68\end{array}$ & $\begin{array}{l}0.702 \\
<0.001 * * *\end{array}$ & $\begin{array}{l}90.49 \pm \\
11.86\end{array}$ \\
\hline WBC & $5.83 \pm 0.77$ & $6.39 \pm 0.40$ & $10.74 \pm 4.24$ & $0.001 * * *$ & $11.54 \pm 4.50$ \\
\hline HGB & $\begin{array}{l}150.98 \pm \\
17.68\end{array}$ & $135.50 \pm 4.08$ & $\begin{array}{l}132.39 \pm \\
20.97\end{array}$ & $\begin{array}{l}<0.001^{* * *} \\
<0.001^{* * *}\end{array}$ & $\begin{array}{l}128.63 \pm \\
17.86\end{array}$ \\
\hline PLT & $\begin{array}{l}173.3 \pm \\
43.14\end{array}$ & $201.35 \pm 13.27$ & $\begin{array}{l}190.59 \pm \\
68.15\end{array}$ & $\begin{array}{l}0.297 \\
0.194\end{array}$ & $\begin{array}{l}199.34 \pm \\
67.05\end{array}$ \\
\hline FPG & $4.97 \pm 4.87$ & $5.54 \pm 0.24$ & $7.21 \pm 2.42$ & $\begin{array}{l}0.744 \\
0.001^{* * *}\end{array}$ & $7.61 \pm 2.84$ \\
\hline SAA & $0.36 \pm 0.08$ & $0.72 \pm 0.40$ & $4.43 \pm 0.31$ & $\begin{array}{l}0.155 \\
<0.001^{* * *} \\
0.029^{*}\end{array}$ & $4.22 \pm 0.33$ \\
\hline
\end{tabular}

Note, AAD-acute aortic dissection; TAAD-type A aortic dissection; TBAD-type B aortic dissection; BMI-body mass index; HR-heart rate; DM-diabetes mellitus; WBC-white blood cell; HGB-hemoglobin; PLT-platelet; FPG-fast plasma glucose; SAA-serum amyloid A 
Table 2 Comparison of SAA levels between AAD and control group, AAD and angina group stratified by cardiovascular risk factors

\begin{tabular}{|c|c|c|c|c|c|c|}
\hline \multirow[t]{2}{*}{ Variables } & & Control & Angina & AAD & P Value & \\
\hline & & $\mathrm{SAA}(\mathrm{ng} / \mathrm{mg})$ & SAA(ng/mg) & SAA(ng/mg) & $\begin{array}{l}\text { AAD vs } \\
\text { Control }\end{array}$ & $\begin{array}{l}\text { AAD vs } \\
\text { angina }\end{array}$ \\
\hline \multirow[t]{2}{*}{ Age } & $<60 y$ & $0.418 \pm 0.113$ & $0.661 \pm 0.333$ & $4.436 \pm 0.308$ & $<0.001$ & 0.033 \\
\hline & $\geq 60 y$ & $0.263 \pm 0.084$ & $0.632 \pm 0.323$ & $6.850 \pm 2.535$ & $<0.001$ & 0.023 \\
\hline \multirow[t]{2}{*}{ Gender } & male & $0.375 \pm 0.093$ & $0.697 \pm 0.295$ & $5.542 \pm 1.456$ & $<0.001$ & 0.014 \\
\hline & female & $0.332 \pm 0.146$ & $0.446 \pm 0.244$ & $5.227 \pm 0.444$ & $<0.001$ & 0.032 \\
\hline \multirow[t]{2}{*}{ BMI } & $<25$ & $0.300 \pm 0.067$ & $0.652 \pm 0.301$ & $5.879 \pm 1.496$ & $<0.001$ & 0.017 \\
\hline & $\geq 25$ & $0.652 \pm 0.316$ & $0.630 \pm 0.364$ & $4.369 \pm 0.494$ & $<0.001$ & 0.016 \\
\hline \multirow[t]{2}{*}{ Hypertension } & Yes & $0.445 \pm 0.164$ & $0.808 \pm 0.204$ & $4.892 \pm 0.517$ & $<0.001$ & 0.024 \\
\hline & No & $0.319 \pm 0.085$ & $0.535 \pm 0.342$ & $6.397 \pm 2.771$ & $<0.001$ & 0.046 \\
\hline \multirow[t]{2}{*}{$\begin{array}{l}\text { Smoking } \\
\text { history }\end{array}$} & Yes & $0.510 \pm 0.215$ & $0.728 \pm 0.326$ & $7.698 \pm 2.990$ & $<0.001$ & 0.006 \\
\hline & No & $0.297 \pm 0.063$ & $0.516 \pm 0.278$ & $4.225 \pm 0.344$ & $<0.001$ & 0.030 \\
\hline \multirow[t]{2}{*}{ DM } & Yes & $0.232 \pm 0.093$ & $0.566 \pm 0.356$ & $8.157 \pm 3.569$ & $<0.001$ & 0.007 \\
\hline & No & $0.385 \pm 0.093$ & $0.677 \pm 0.311$ & $4.314 \pm 0.317$ & $<0.001$ & 0.047 \\
\hline
\end{tabular}

Note, AAD-acute aortic dissection; BMI-body mass index; DM-diabetes mellitus; SAAserum amyloid A 
ble 3 Comparisons of blood parameters between different sub-groups in AAD patient group

Page $17 / 27$ 
eters TAAD TBAD $\quad \mathrm{P}$ value less than more than $\mathrm{P}$ value communicating non-communicating $\quad \mathrm{P} \quad \mathrm{Death} \quad$ Survival $\mathrm{P}$ value

$$
6 \mathrm{~h} \quad 6 \mathrm{~h} \quad \text { false false lumen value }
$$

lumen

\begin{tabular}{|c|c|c|c|c|c|c|c|c|c|c|c|c|}
\hline & $\begin{array}{c}11.54 \pm \\
4.5\end{array}$ & $\begin{array}{c}10.06 \pm \\
3.92\end{array}$ & 198 & $\begin{array}{c}10.73 \pm \\
4.75\end{array}$ & $\begin{array}{c}10.75 \pm \\
3.78\end{array}$ & 0.917 & $12.1 \pm$ & 74 & 0.522 & $\begin{array}{c}12.78 \pm \\
4.05\end{array}$ & $\begin{array}{c}9.96 \pm \\
4.08\end{array}$ & .004 \\
\hline $3 \mathrm{C}$ & $\begin{array}{c}0.20 \pm \\
0.23\end{array}$ & $\begin{array}{c}0.28 \pm \\
0.34\end{array}$ & 0.646 & $\begin{array}{c}0.24 \pm \\
0.3\end{array}$ & $\begin{array}{c}0.25 \pm \\
0.30\end{array}$ & 0.723 & $03+$ & 023 & 231 & $\begin{array}{c}0.22 \pm \\
0.21\end{array}$ & $\begin{array}{c}0.26 \pm \\
0.32\end{array}$ & 954 \\
\hline $3 \mathrm{C}$ & $\begin{array}{c}1.37 \pm \\
1.65\end{array}$ & $\begin{array}{c}0.89 \pm \\
1.51\end{array}$ & 0.139 & $\begin{array}{c}0.95 \pm \\
1.37\end{array}$ & $\begin{array}{c}1.26 \pm \\
1.76\end{array}$ & 0.409 & $1.04 \pm 1.34$ & $1.13 \pm 1.65$ & .783 & $\begin{array}{c}0.66 \pm \\
1.06\end{array}$ & $\begin{array}{c}1.28 \pm \\
1.72\end{array}$ & $0.039 *$ \\
\hline $\mathrm{BC}$, & $\begin{array}{c}13.29 \pm \\
14.10\end{array}$ & $\begin{array}{c}8.48 \pm \\
9.03\end{array}$ & $0.002 * *$ & $\begin{array}{c}9.29 \pm \\
7.37\end{array}$ & $\begin{array}{c}11.96 \pm \\
14.7\end{array}$ & 0.909 & $5.02 \pm 19.28$ & $9.63 \pm 9.04$ & 0.648 & $\begin{array}{c}9.21 \pm \\
9.16\end{array}$ & $\begin{array}{c}11.26 \pm \\
12.71\end{array}$ & 0.227 \\
\hline $3 \mathrm{C}$ & $\begin{array}{c}14.87 \pm \\
9.26\end{array}$ & $\begin{array}{c}15.98 \pm \\
9.1\end{array}$ & 0.462 & $\begin{array}{c}14.76 \pm \\
8.5\end{array}$ & $\begin{array}{c}16.1 \pm \\
9.72\end{array}$ & 0.596 & $14.24 \pm 8.78$ & $15.77=$ & 0.514 & $\begin{array}{c}11.62 \pm \\
5.68\end{array}$ & $\begin{array}{c}16.94 \pm \\
9.79\end{array}$ & $0.043 *$ \\
\hline 3C, & $\begin{array}{c}69.92 \pm \\
15.24\end{array}$ & $\begin{array}{c}74.31 \pm \\
12.97\end{array}$ & 0.198 & $\begin{array}{c}74.49 \pm \\
12.41\end{array}$ & $\begin{array}{c}70.31 \pm \\
15.41\end{array}$ & 0.275 & $69.4 \pm 18.71$ & $73 \pm 1$ & 0.638 & $\begin{array}{c}77.88 \pm \\
10.9\end{array}$ & $\begin{array}{c}70.15 \pm \\
14.72\end{array}$ & $0.017 *$ \\
\hline $\mathrm{L}$ & $\begin{array}{c}4.26 \pm \\
0.64\end{array}$ & $\begin{array}{c}4.52 \pm \\
0.76\end{array}$ & $0.014^{*}$ & $\begin{array}{c}4.36 \pm \\
0.65\end{array}$ & $\begin{array}{c}4.43 \pm \\
0.77\end{array}$ & 0.730 & $4.32 \pm$ & $4.42 \pm$ & 523 & $\begin{array}{c}4.46 \pm \\
0.82\end{array}$ & $\begin{array}{c}4.38 \pm \\
0.68\end{array}$ & 0.582 \\
\hline $\mathrm{s} / \mathrm{L}$ & $\begin{array}{c}128.63 \pm \\
17.86\end{array}$ & $\begin{array}{c}135.61 \pm \\
23.03\end{array}$ & 0.052 & $\begin{array}{c}134.92 \pm \\
18.44\end{array}$ & $\begin{array}{c}130.13 \pm \\
23\end{array}$ & 0.328 & $26.73 \pm 27.9$ & $33.79 \pm 18.92$ & 497 & $\begin{array}{c}131.19 \pm \\
25.29\end{array}$ & $\begin{array}{c}132.85 \pm \\
19.31\end{array}$ & 0.968 \\
\hline pg & $\begin{array}{c}30.45 \pm \\
3.12\end{array}$ & $\begin{array}{c}30.49 \pm \\
1.94\end{array}$ & 0.373 & $\begin{array}{c}31.06 \pm \\
2.15\end{array}$ & $\begin{array}{c}29.94 \pm \\
2.75\end{array}$ & $0.015^{*}$ & $29.89 \pm 4.59$ & $30.61 \pm 1.73$ & 0.958 & $\begin{array}{c}29.68 \pm \\
3.41\end{array}$ & $\begin{array}{c}30.77 \pm \\
2.07\end{array}$ & 0.104 \\
\hline L & $\begin{array}{c}91.66 \pm \\
8.00\end{array}$ & $\begin{array}{c}92.11 \pm \\
5.52\end{array}$ & 0.696 & $\begin{array}{c}93.2 \pm \\
5.67\end{array}$ & $\begin{array}{c}90.74 \pm \\
7.43\end{array}$ & 0.181 & $0.10 \pm 11.44$ & $92.35 \pm$ & 681 & $\begin{array}{c}89.83 \pm \\
9.28\end{array}$ & $\begin{array}{c}92.69 \pm \\
5.36\end{array}$ & 0.168 \\
\hline $\mathrm{g} / \mathrm{L}$ & $\begin{array}{c}331.77 \pm \\
11.11\end{array}$ & $\begin{array}{c}331.12 \pm \\
11.83\end{array}$ & 0.731 & $\begin{array}{c}333.17 \pm \\
9.78\end{array}$ & $\begin{array}{c}329.85 \pm \\
12.65\end{array}$ & 0.348 & $330.8 \pm 17.09$ & $331.57 \pm 9.75$ & 45 & $\begin{array}{c}329.81 \pm \\
11.29\end{array}$ & $\begin{array}{c}332.04 \pm \\
11.53\end{array}$ & 183 \\
\hline ـ/L & $\begin{array}{c}0.38 \pm \\
0.06\end{array}$ & $\begin{array}{c}0.41 \pm \\
0.07\end{array}$ & 0.083 & $\begin{array}{c}0.41 \pm \\
0.06\end{array}$ & $\begin{array}{c}0.39 \pm \\
0.08\end{array}$ & 0.428 & $0.38 \pm 0.09$ & $0.40 \pm 0.06$ & 0.567 & $\begin{array}{c}0.39 \pm \\
0.08\end{array}$ & $\begin{array}{c}0.40 \pm \\
0.06\end{array}$ & 0.802 \\
\hline$\%$ & $\begin{array}{c}13.73 \pm \\
2.43\end{array}$ & $\begin{array}{c}13.25 \pm \\
1.3\end{array}$ & 0.864 & $\begin{array}{c}13.38 \pm \\
1.47\end{array}$ & $\begin{array}{c}13.51 \pm \\
2.17\end{array}$ & 0.753 & $14.26 \pm 2.64$ & $13.25 \pm$ & 0.253 & $\begin{array}{c}13.74 \pm \\
1.78\end{array}$ & $\begin{array}{c}13.33 \pm \\
1.89\end{array}$ & 0.089 \\
\hline & $\begin{array}{c}199.34 \pm \\
67.05\end{array}$ & $\begin{array}{c}183.12 \pm \\
69\end{array}$ & 0.196 & $\begin{array}{c}177.75 \pm \\
64.26\end{array}$ & $\begin{array}{c}202.15 \pm \\
70.25\end{array}$ & 0.218 & $166.07 \pm 62.69$ & $196.62 \pm 68.56$ & 68 & $\begin{array}{c}182.33 \pm \\
59.6\end{array}$ & $\begin{array}{c}193.75 \pm \\
71.4\end{array}$ & 597 \\
\hline $\mathrm{L}$ & $\begin{array}{c}9.48 \pm \\
1.13\end{array}$ & $\begin{array}{c}9.93 \pm \\
1.67\end{array}$ & 0.158 & $\begin{array}{c}9.95 \pm \\
1.43\end{array}$ & $\begin{array}{c}9.52 \pm \\
1.46\end{array}$ & 0.380 & $9.51 \pm 1.77$ & $9.77 \pm 1.39$ & 0.675 & $\begin{array}{c}9.91 \pm \\
1.06\end{array}$ & $\begin{array}{c}9.65 \pm \\
1.58\end{array}$ & .480 \\
\hline$/ \mathrm{L}$ & $\begin{array}{c}1.02 \pm \\
2.26\end{array}$ & $\begin{array}{c}0.36 \pm \\
1.11\end{array}$ & 0.076 & $\begin{array}{c}0.80 \pm \\
1.99\end{array}$ & $\begin{array}{c}0.56 \pm \\
1.54\end{array}$ & 0.264 & $1.22 \pm 2.57$ & $0.55+$ & 0.670 & $\begin{array}{c}0.87 \pm \\
2.10\end{array}$ & $\begin{array}{c}0.59 \pm \\
1.62\end{array}$ & 0.472 \\
\hline & $\begin{array}{c}14.51 \pm \\
2.72\end{array}$ & $\begin{array}{c}14.4 \pm \\
2.90\end{array}$ & 0.657 & $\begin{array}{c}14.9 \pm \\
3.00\end{array}$ & $\begin{array}{c}14.06 \pm \\
2.59\end{array}$ & 0.260 & $15.26 \pm 2.12$ & $14.27 \pm 2.91$ & 308 & $\begin{array}{c}14.51 \pm \\
2.53\end{array}$ & $\begin{array}{c}14.42 \pm \\
2.92\end{array}$ & 489 \\
\hline 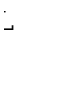 & $\begin{array}{c}63.93 \pm \\
7.68\end{array}$ & $\begin{array}{c}63.78 \pm \\
10.34\end{array}$ & 0.540 & $\begin{array}{c}64.76 \pm \\
8.76\end{array}$ & $\begin{array}{c}63.05 \pm \\
9.56\end{array}$ & 0.410 & $61.72 \pm 9.1$ & $64.38 \pm 9$ & 277 & $\begin{array}{c}62.27 \pm \\
10.19\end{array}$ & $\begin{array}{c}64.46 \pm \\
8.77\end{array}$ & .591 \\
\hline r/dL & $\begin{array}{c}15.96 \pm \\
6.67\end{array}$ & $\begin{array}{c}17.71 \pm \\
6.29\end{array}$ & 0.231 & $\begin{array}{c}14.18 \pm \\
6.55\end{array}$ & $\begin{array}{c}18.88 \pm \\
5.74\end{array}$ & $0.005^{* *}$ & $16.94 \pm 6.67$ & $1678+$ & 0.868 & $\begin{array}{c}14.75 \pm \\
5.06\end{array}$ & $\begin{array}{c}17.56 \pm \\
6.83\end{array}$ & 0.177 \\
\hline$/ \mathrm{L}$ & $\begin{array}{c}35.75 \pm \\
6.12\end{array}$ & $\begin{array}{c}36.84 \pm \\
6.93\end{array}$ & 0.341 & $\begin{array}{c}37.03 \pm \\
6.36\end{array}$ & $\begin{array}{c}35.75 \pm \\
6.74\end{array}$ & 0.470 & $34.45 \pm 7.3$ & $36.82 \pm 6.34$ & 0.185 & $\begin{array}{c}36.63 \pm \\
7.29\end{array}$ & $\begin{array}{c}36.23 \pm \\
6.32\end{array}$ & 0.813 \\
\hline r/L & $\begin{array}{c}106.79 \pm \\
81.75\end{array}$ & $\begin{array}{c}99.61 \pm \\
43.41\end{array}$ & 0.583 & $\begin{array}{c}104.84 \pm \\
59.66\end{array}$ & $\begin{array}{c}100.79 \pm \\
66.18\end{array}$ & 0.793 & $102.42 \pm 62.9$ & $102.83 \pm 63.19$ & 25 & $\begin{array}{c}103 \pm \\
59.7\end{array}$ & $\begin{array}{c}102.66 \pm \\
64.29\end{array}$ & 0.773 \\
\hline r/L & $\begin{array}{c}140.94 \pm \\
407.11\end{array}$ & $\begin{array}{c}57.24 \pm \\
61.02\end{array}$ & 0.151 & $\begin{array}{c}91.74 \pm \\
203.78\end{array}$ & $\begin{array}{l}98.2 \pm \\
333.43\end{array}$ & 10 & $\begin{array}{c}119.07 \pm \\
305.66\end{array}$ & $89.22 \pm$ & 408 & $\begin{array}{c}147.86 \pm \\
454.6\end{array}$ & $\begin{array}{l}74.7 \pm \\
170.15\end{array}$ & 0.224 \\
\hline r/L & $\begin{array}{c}94 \pm \\
364.89\end{array}$ & $\begin{array}{c}60.56 \pm \\
101.49\end{array}$ & 0.249 & $\begin{array}{c}59.69 \pm \\
101.85\end{array}$ & $\begin{array}{c}91.36 \pm \\
346.71\end{array}$ & 0.502 & $43.86 \pm 45.18$ & $83.97 \pm 288.02$ & 0.709 & $\begin{array}{c}170.45 \pm \\
488.11\end{array}$ & $\begin{array}{c}41.54 \pm \\
56.58\end{array}$ & 0.123 \\
\hline$J / L$ & $\begin{array}{c}128.38 \pm \\
212.94\end{array}$ & $\begin{array}{c}94.02 \pm \\
122.55\end{array}$ & 0.766 & $\begin{array}{c}139.77 \pm \\
181.81\end{array}$ & $\begin{array}{l}83.2 \pm \\
154.87\end{array}$ & 0.057 & $127.2 \pm 192.56$ & $105.2 \pm 164.37$ & 0.942 & $\begin{array}{c}99.95 \pm \\
158.57\end{array}$ & $\begin{array}{c}113.35 \pm \\
174.47\end{array}$ & 0.402 \\
\hline$/ \mathrm{L}$ & $\begin{array}{c}6.02 \pm \\
1.65\end{array}$ & $\begin{array}{c}5.96 \pm \\
1.71\end{array}$ & 0.666 & $\begin{array}{c}5.70 \pm \\
1.54\end{array}$ & $\begin{array}{c}6.22 \pm \\
1.74\end{array}$ & 0.247 & $5.48 \pm 1.68$ & $6.13 \pm 1.65$ & 0.273 & $\begin{array}{c}5.83 \pm \\
1.54\end{array}$ & $\begin{array}{c}6.05 \pm \\
1.72\end{array}$ & 0.599 \\
\hline 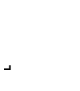 & $\begin{array}{c}4.76 \pm \\
4.87\end{array}$ & $\begin{array}{c}4.16 \pm \\
5.86\end{array}$ & 0.312 & $\begin{array}{c}5.84 \pm \\
7.11\end{array}$ & $\begin{array}{c}3.36 \pm \\
2.95\end{array}$ & 0.170 & $4.19 \pm 3.29$ & $4.54 \pm 5.79$ & 0.873 & $\begin{array}{c}3.15 \pm \\
2.67\end{array}$ & $\begin{array}{c}4.95 \pm \\
5.97\end{array}$ & 0.415 \\
\hline & $\begin{array}{c}8.93 \pm \\
9.78\end{array}$ & $\begin{array}{c}5.77 \pm \\
2.84\end{array}$ & 0.493 & $\begin{array}{c}9.7 \pm \\
10.4\end{array}$ & $\begin{array}{c}5.66 \pm \\
3.36\end{array}$ & 0.122 & $8.72 \pm 7.26$ & $7.31 \pm 8.06$ & 0.463 & $\begin{array}{c}6.58 \pm \\
3.14\end{array}$ & $\begin{array}{c}7.95 \pm \\
8.77\end{array}$ & 0.815 \\
\hline
\end{tabular}




\begin{tabular}{|c|c|c|c|c|c|c|c|c|c|c|c|c|}
\hline & $\begin{array}{c}17.95 \pm \\
14.17\end{array}$ & $\begin{array}{c}16.75 \pm \\
8.70\end{array}$ & 0.568 & $\begin{array}{c}20.2 \pm \\
14.67\end{array}$ & $\begin{array}{c}14.81 \pm \\
6.88\end{array}$ & 103 & $37 \pm$ & 8 & .389 & $\begin{array}{c}16.06 \pm \\
8.68\end{array}$ & $\begin{array}{c}17.74 \pm \\
12.29\end{array}$ & 742 \\
\hline L & $\begin{array}{c}186.1 \pm \\
220.13\end{array}$ & $\begin{array}{c}382 \pm \\
1184.96\end{array}$ & 0.865 & $\begin{array}{c}217.87 \pm \\
314.36\end{array}$ & $\begin{array}{c}360.08 \pm \\
1186.69\end{array}$ & 0.940 & $\begin{array}{c}287.88 \pm \\
338.95\end{array}$ & $295.68 \pm 974.92$ & 0.122 & $\begin{array}{c}562.31 \pm \\
1711.62\end{array}$ & $\begin{array}{c}203.15 \pm \\
288.52\end{array}$ & 0.645 \\
\hline $\mathrm{U} / \mathrm{L}$ & $\begin{array}{c}17.95 \pm \\
9.85\end{array}$ & $\begin{array}{c}22.39 \pm \\
22.55\end{array}$ & 0.343 & $\begin{array}{c}18.16 \pm \\
8.53\end{array}$ & $\begin{array}{c}21.32 \pm \\
21.17\end{array}$ & 0.930 & $18.23 \pm 9.23$ & $20.25 \pm 17.83$ & 0.914 & $\begin{array}{c}26.84 \pm \\
28.62\end{array}$ & $\begin{array}{c}17.31 \pm \\
8.18\end{array}$ & 0.607 \\
\hline [ & $\begin{array}{c}7.56 \pm \\
3.99\end{array}$ & $\begin{array}{c}7.94 \pm \\
8.41\end{array}$ & 0.127 & $\begin{array}{c}7.84 \pm \\
6.95\end{array}$ & $7.7 \pm 6.56$ & 0.640 & $8.29 \pm 5$ & $7.64 \pm$ & 0.296 & $\begin{array}{c}7.87 \pm \\
4.51\end{array}$ & $\begin{array}{c}7.73 \pm \\
7.41\end{array}$ & 0.646 \\
\hline L & $\begin{array}{c}273.5 \pm \\
159.03\end{array}$ & $\begin{array}{c}352.75 \pm \\
214.01\end{array}$ & 0.280 & $\begin{array}{c}332.93 \pm \\
185.1\end{array}$ & $\begin{array}{c}277.47 \pm \\
184.43\end{array}$ & 0.213 & $\begin{array}{c}314.57 \pm \\
211.96\end{array}$ & $302.35 \pm 179.47$ & 0.623 & $\begin{array}{c}376.29 \pm \\
204.76\end{array}$ & $\begin{array}{c}283.57 \pm \\
175.97\end{array}$ & 0.177 \\
\hline L & $\begin{array}{c}91.22 \pm \\
43.83\end{array}$ & $\begin{array}{c}111.17 \pm \\
82.2\end{array}$ & 0.789 & $\begin{array}{c}110.42 \pm \\
66.54\end{array}$ & $\begin{array}{c}88.13 \pm \\
55.74\end{array}$ & 0.083 & $99.33 \pm 70.69$ & $98.91 \pm 59.94$ & 0.614 & $\begin{array}{c}100.3 \pm \\
22.1\end{array}$ & $\begin{array}{c}98.58 \pm \\
69.99\end{array}$ & 0.054 \\
\hline & $\begin{array}{c}1.30 \pm \\
0.53\end{array}$ & $\begin{array}{c}1.42 \pm \\
0.95\end{array}$ & 0.990 & $\begin{array}{c}1.38 \pm \\
0.79\end{array}$ & $\begin{array}{c}1.34 \pm \\
0.73\end{array}$ & 0.654 & $1.54 \pm 0.84$ & $1.32 \pm 0.74$ & 0.412 & $\begin{array}{c}1.35 \pm \\
0.63\end{array}$ & $\begin{array}{c}1.36 \pm \\
0.81\end{array}$ & 0.837 \\
\hline L & $\begin{array}{c}182.2 \pm \\
35.56\end{array}$ & $\begin{array}{c}200.05 \pm \\
38.89\end{array}$ & 0.172 & $\begin{array}{c}177.55 \pm \\
36.91\end{array}$ & $\begin{array}{c}198.33 \pm \\
35.83\end{array}$ & 0.074 & $181.63 \pm$ & 191. & .763 & $\begin{array}{c}176.91 \pm \\
31.95\end{array}$ & $\begin{array}{c}191.81 \pm \\
38.46\end{array}$ & 0.563 \\
\hline L & $\begin{array}{c}138.48 \pm \\
4.85\end{array}$ & $\begin{array}{c}141.52 \pm \\
6.29\end{array}$ & $0.037^{*}$ & $\begin{array}{c}140.08 \pm \\
7.12\end{array}$ & $\begin{array}{c}140.15 \pm \\
4.48\end{array}$ & 0.731 & $139.35 \pm 8.79$ & $140.3 \pm 4.94$ & 0.293 & $\begin{array}{c}140.66 \pm \\
6.7\end{array}$ & $\begin{array}{c}139.91 \pm \\
5.53\end{array}$ & 0.991 \\
\hline$) \mathrm{l} / \mathrm{L}$ & $\begin{array}{c}3.63 \pm \\
0.87\end{array}$ & $\begin{array}{c}4.27 \pm \\
0.66\end{array}$ & $0.015^{*}$ & $\begin{array}{c}3.92 \pm \\
0.62\end{array}$ & $\begin{array}{c}3.84 \pm \\
1.02\end{array}$ & 0.724 & $4.18 \pm 0.42$ & $3.79 \pm 0.91$ & 0.095 & $3.7 \pm 1.14$ & $\begin{array}{c}3.94 \pm \\
0.74\end{array}$ & 0.274 \\
\hline L & $\begin{array}{c}103.36 \pm \\
5.92\end{array}$ & $\begin{array}{c}111.18 \pm \\
7.39\end{array}$ & $0.000 * * *$ & $\begin{array}{c}104.75 \pm \\
8.74\end{array}$ & $108 \pm 5.91$ & 0.052 & $105.88 \pm 11.64$ & $106.56 \pm 6.14$ & 0.875 & $\begin{array}{c}108.57 \pm \\
8.95\end{array}$ & $\begin{array}{c}105.71 \pm \\
7.01\end{array}$ & 0.704 \\
\hline L & $\begin{array}{c}24.15 \pm \\
2.41\end{array}$ & $\begin{array}{c}23.98 \pm \\
2.95\end{array}$ & 0.767 & $\begin{array}{c}24.37 \pm \\
2.47\end{array}$ & $\begin{array}{c}23.76 \pm \\
2.92\end{array}$ & 0.236 & $23.71 \pm 2.39$ & $24.14 \pm 2.79$ & 0.341 & $\begin{array}{c}22.42 \pm \\
2.71\end{array}$ & $\begin{array}{c}24.69 \pm \\
2.45\end{array}$ & $0.011 *$ \\
\hline ue & $\begin{array}{c}6.93 \pm \\
0.69\end{array}$ & $\begin{array}{c}6.49 \pm \\
1.08\end{array}$ & 0.106 & $\begin{array}{c}7.06 \pm \\
0.6\end{array}$ & $\begin{array}{c}6.44 \pm \\
1.02\end{array}$ & $0.021 *$ & $6.5 \pm 1.04$ & $6.81 \pm 0.85$ & 0.915 & $6.8 \pm 0.81$ & $\begin{array}{c}6.73 \pm \\
0.93\end{array}$ & 0.649 \\
\hline L & $\begin{array}{c}4.19 \pm \\
0.83\end{array}$ & $\begin{array}{c}4.59 \pm \\
1.17\end{array}$ & 0.255 & $\begin{array}{c}4.62 \pm \\
1.32\end{array}$ & $4.3 \pm 0.84$ & 0.589 & $4.92 \pm 1.47$ & $4.32 \pm 0.93$ & 0.361 & $\begin{array}{c}4.51 \pm \\
1.13\end{array}$ & $\begin{array}{c}4.39 \pm \\
1.03\end{array}$ & 0.333 \\
\hline 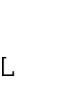 & $\begin{array}{c}1.34 \pm \\
0.56\end{array}$ & $\begin{array}{c}1.34 \pm \\
0.67\end{array}$ & 0.834 & $\begin{array}{c}1.24 \pm \\
0.47\end{array}$ & $\begin{array}{c}1.41 \pm \\
0.71\end{array}$ & 0.677 & $1.5 \pm 0.57$ & $1.31 \pm 0.63$ & 0.283 & $\begin{array}{c}1.23 \pm \\
0.44\end{array}$ & $\begin{array}{c}1.39 \pm \\
0.69\end{array}$ & 0.664 \\
\hline L & $\begin{array}{c}1.14 \pm \\
0.18\end{array}$ & $\begin{array}{c}1.21 \pm \\
0.22\end{array}$ & 0.469 & $\begin{array}{c}1.18 \pm \\
0.17\end{array}$ & $\begin{array}{c}1.18 \pm \\
0.22\end{array}$ & 0.938 & $1.14 \pm 0.31$ & $1.19 \pm 0.18$ & 0.776 & $\begin{array}{c}1.24 \pm \\
0.16\end{array}$ & $\begin{array}{c}1.14 \pm \\
0.22\end{array}$ & 0.218 \\
\hline L & $\begin{array}{c}0.85 \pm \\
0.22\end{array}$ & $\begin{array}{c}0.76 \pm \\
0.13\end{array}$ & 0.674 & $\begin{array}{c}0.75 \pm \\
0.22\end{array}$ & $\begin{array}{c}0.83 \pm \\
0.13\end{array}$ & 0.277 & $0.85 \pm 0.13$ & $0.79 \pm 0.18$ & 0.506 & $0.76 \pm 0.2$ & $\begin{array}{c}0.82 \pm \\
0.16\end{array}$ & 0.425 \\
\hline 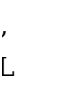 & $\begin{array}{c}2.58 \pm \\
0.78\end{array}$ & $\begin{array}{c}2.87 \pm \\
1.06\end{array}$ & 0.246 & $\begin{array}{c}2.87 \pm \\
1.04\end{array}$ & $\begin{array}{c}2.68 \pm \\
0.92\end{array}$ & 0.620 & $3.23 \pm 1.00$ & $2.66 \pm 0.94$ & 0.133 & $\begin{array}{c}2.65 \pm \\
1.05\end{array}$ & $\begin{array}{c}2.81 \pm \\
0.93\end{array}$ & 0.899 \\
\hline L & $\begin{array}{c}1.08 \pm \\
0.34\end{array}$ & $\begin{array}{c}1.22 \pm \\
0.31\end{array}$ & 0.139 & $\begin{array}{c}1.18 \pm \\
0.25\end{array}$ & $\begin{array}{c}1.16 \pm \\
0.37\end{array}$ & 0.649 & $1.09 \pm 0.38$ & $.19 \pm 0.31$ & 0.570 & $\begin{array}{c}1.25 \pm \\
0.25\end{array}$ & $\begin{array}{c}1.13 \pm \\
0.35\end{array}$ & 0.150 \\
\hline $\mathrm{J} / \mathrm{L}$ & $\begin{array}{c}451.88 \pm \\
779.15\end{array}$ & $\begin{array}{c}487.03 \pm \\
489.75\end{array}$ & 0.138 & $\begin{array}{c}505.85 \pm \\
538.16\end{array}$ & $\begin{array}{c}444.28 \pm \\
694.87\end{array}$ & 0.171 & $\begin{array}{c}410.67 \pm \\
242.15\end{array}$ & $487.85 \pm 692.2$ & 0.645 & $\begin{array}{c}826.64 \pm \\
1148.14\end{array}$ & $\begin{array}{c}359 \pm \\
255.33\end{array}$ & $0.036^{*}$ \\
\hline & $\begin{array}{c}1.14 \pm \\
0.22\end{array}$ & $\begin{array}{c}1.08 \pm \\
0.11\end{array}$ & 0.446 & $\begin{array}{c}1.13 \pm \\
0.21\end{array}$ & $\begin{array}{c}1.09 \pm \\
0.13\end{array}$ & 0.172 & $1.09 \pm 0.12$ & $1.11 \pm 0.18$ & 0.788 & $\begin{array}{c}1.18 \pm \\
0.26\end{array}$ & $\begin{array}{c}1.08 \pm \\
0.10\end{array}$ & 0.152 \\
\hline & $\begin{array}{c}13.11 \pm \\
2.41\end{array}$ & $\begin{array}{c}13.28 \pm \\
1.33\end{array}$ & 0.149 & $\begin{array}{c}13.51 \pm \\
2.27\end{array}$ & $\begin{array}{c}12.96 \pm \\
1.51\end{array}$ & 0.119 & $12.9 \pm 1.57$ & $13.28 \pm 1.96$ & 0.634 & $\begin{array}{c}13.91 \pm \\
2.65\end{array}$ & $\begin{array}{c}12.89 \pm \\
1.36\end{array}$ & 0.131 \\
\hline & $\begin{array}{c}85.87 \pm \\
17.42\end{array}$ & $\begin{array}{c}89.28 \pm \\
12.04\end{array}$ & 0.615 & $\begin{array}{c}85.62 \pm \\
16.02\end{array}$ & $\begin{array}{c}89.38 \pm \\
13.59\end{array}$ & 0.198 & $88.54 \pm 13.99$ & $87.53 \pm 15.01$ & 0.974 & $\begin{array}{c}83.4 \pm \\
19.2\end{array}$ & $\begin{array}{c}89.61 \pm \\
12.04\end{array}$ & 0.279 \\
\hline S & $\begin{array}{c}32.28 \pm \\
5.28\end{array}$ & $\begin{array}{c}35.79 \pm \\
5.86\end{array}$ & $0.008 * *$ & $\begin{array}{c}34.39 \pm \\
6.11\end{array}$ & $\begin{array}{c}34.04 \pm \\
5.69\end{array}$ & 0.948 & $34.42 \pm 6.43$ & $34.14 \pm 5.75$ & 0.834 & $35.4 \pm 6.4$ & $\begin{array}{c}33.67 \pm \\
5.57\end{array}$ & 0.339 \\
\hline ᄂ & $\begin{array}{c}7.61 \pm \\
2.84\end{array}$ & $\begin{array}{c}6.92 \pm \\
2.05\end{array}$ & 0.355 & $\begin{array}{c}7.2 \pm \\
1.92\end{array}$ & $\begin{array}{c}7.22 \pm \\
2.81\end{array}$ & 0.281 & $6.38 \pm 1.63$ & $7.45 \pm 2.57$ & 0.069 & $\begin{array}{c}7.90 \pm \\
2.25\end{array}$ & $\begin{array}{c}6.92 \pm \\
2.46\end{array}$ & $0.032 *$ \\
\hline $\mathrm{ng} / \mathrm{L}$ & $\begin{array}{c}95.73 \pm \\
60.92\end{array}$ & $\begin{array}{c}70.53 \pm \\
76.14\end{array}$ & 0.115 & $\begin{array}{c}90.4 \pm \\
83.01\end{array}$ & $\begin{array}{c}71.92 \pm \\
61.85\end{array}$ & 0.597 & $79.43 \pm 84.49$ & $79.81 \pm 69.09$ & 0.889 & $\begin{array}{c}138.21 \pm \\
68.8\end{array}$ & $\begin{array}{c}48.78 \pm \\
50.86\end{array}$ & $0.000 * * *$ \\
\hline \multirow[t]{2}{*}{ r, } & $\begin{array}{c}2.02 \pm \\
3.57\end{array}$ & $\begin{array}{c}4.10 \pm \\
5.73\end{array}$ & 0.187 & $\begin{array}{c}3.25 \pm \\
4.94\end{array}$ & $\begin{array}{c}3.09 \pm \\
5.02\end{array}$ & 0.234 & $1.81 \pm 1.69$ & $3.49 \pm 5.42$ & 0.759 & $\begin{array}{c}6.20 \pm \\
6.91\end{array}$ & $\begin{array}{c}1.83 \pm \\
3.05\end{array}$ & $0.006^{* *}$ \\
\hline & $\begin{array}{c}4.22 \pm \\
0.33\end{array}$ & $\begin{array}{c}4.58 \pm \\
0.48\end{array}$ & 0.595 & $\begin{array}{c}4.61 \pm \\
0.42\end{array}$ & $\begin{array}{c}4.21 \pm \\
0.45\end{array}$ & 0.582 & $5.28 \pm 0.81$ & $4.44 \pm 0.51$ & 0.416 & $\begin{array}{c}6.21 \pm \\
0.65\end{array}$ & $\begin{array}{c}3.78 \pm \\
0.31\end{array}$ & $0.001 * * *$ \\
\hline
\end{tabular}


ody Mass Index; HR, heart rate; WBC, white blood cells; RBC, red blood cells; HGB, hemoglobin; PLT, Platelet; BA, basophil; EO, phil; LY, lymphocyte; MO, monocyte; NE, neutrophil; $\mathrm{MCH}$, mean corpuscular hemoglobin; MCHC, mean corpuscular hemoglobin itration; MCV, mean corpuscular Volume; MPV, mean platelet volume; HCT, hematocrit; PCT, platelet hematocrit; PDW, platelet ation width; RDW, red blood cell volume distribution width; APTT, activated partial thromboplastin time; PT, prothrombin time; PTA, Jmbin activity, INR, international normalized ratio; CK, creatine kinase; CKMB, creatine kinase isoenzyme MB; CRP, C-reactive 1; ALB, albumin; ALP, alkaline phosphatase; ALT, alanine aminotransferase; AST, aspartate aminotransferase; DBIL, direct dilirubin; otal bilirubin; CHE, cholinesterase; GGT, gamma glutamyl transpeptidase; TBA, total bile acid; TP, total protein; PA, pre-albumin; LDH, dehydrogenase; Na, serum sodium; CL, serum chlorine; Crea, Creatinine; CYSC, Cystatin C; K, serum kalium; ApoA1, apolipoprotein ıB, apolipoprotein B; FPG, fasting plasma glucose; HDL-C, high-density lipoprotein-cholesterol; TC, total cholesterol; TG, triglycerides; , low-density lipoprotein-cholesterol.

15; **P $<0.01 ; * * * \mathrm{P}<0.001$

correlations between SAA levels and clinical features in AAD patients

\begin{tabular}{|c|c|c|c|c|c|}
\hline ation Indices & $\mathrm{R}$ & $\mathrm{P}$ value & Characterization Indices & $\mathrm{R}$ & $\mathrm{P}$ value \\
\hline \multirow[b]{2}{*}{ ge, Yr } & \multirow[b]{2}{*}{-0.045} & \multirow[b]{2}{*}{0.584} & \multicolumn{3}{|l|}{ Liver function } \\
\hline & & & ALB, $g / L$ & -0.237 & $0.040 *$ \\
\hline BMI & 0.126 & 0.123 & ALP, U/L & 0.124 & 0.330 \\
\hline $\mathrm{HR}, \mathrm{bmp}$ & $0.333<$ & $<0.001 * * *$ & $\mathrm{ALT}, \mathrm{U} / \mathrm{L}$ & 0.121 & 0.300 \\
\hline 1e & \multirow{2}{*}{\multicolumn{2}{|c|}{$0.614<0.001^{* * *}$}} & AST, U/L & 0.163 & 0.166 \\
\hline WBC, $\times 10^{9} / \mathrm{L}$ & & & DBIL, umol/L & -0.098 & 0.553 \\
\hline $\mathrm{RBC}, \times 10^{12} / \mathrm{L}$ & -0.111 & 0.354 & TBIL, umol/L & 0.012 & 0.922 \\
\hline $\mathrm{HGB}, \mathrm{g} / \mathrm{L}$ & $-0.395<$ & $<0.001 * * *$ & CHE, $1000 \mathrm{U} / \mathrm{L}$ & -0.258 & 0.053 \\
\hline $\mathrm{PLT}, \times 10^{9} / \mathrm{L}$ & 0.091 & 0.285 & GGT, U/L & 0.028 & 0.811 \\
\hline BA, $\times 10^{9} / \mathrm{L}$ & -0.101 & 0.385 & TBA, umol/L & 0.138 & 0.310 \\
\hline $\mathrm{EO}, \times 10^{9} / \mathrm{L}$ & -0.243 & $0.035^{*}$ & $\mathrm{TP}, \mathrm{g} / \mathrm{L}$ & -0.177 & 0.128 \\
\hline $\mathrm{LY}, \times 10^{9} / \mathrm{L}$ & -0.168 & 0.147 & $\mathrm{PA}, \mathrm{mg} / \mathrm{dL}$ & -0.402 & $0.002^{* *}$ \\
\hline $\mathrm{MO}, \times 10^{9} / \mathrm{L}$ & 0.085 & 0.468 & $\mathrm{LDH}, \mathrm{U} / \mathrm{L}$ & 0.357 & $0.006 * *$ \\
\hline $\mathrm{NE}, \times 10^{9} / \mathrm{L}$ & 0.257 & $0.025 *$ & \multicolumn{3}{|c|}{ Renal function and serum electrolyte } \\
\hline $\mathrm{MCH}, \mathrm{pg}$ & -0.065 & 0.574 & $\mathrm{Na}, \mathrm{mmol} / \mathrm{L}$ & -0.141 & 0.224 \\
\hline $\mathrm{MCHC}, \mathrm{g} / \mathrm{L}$ & -0.202 & 0.080 & $\mathrm{C} 1 \mathrm{q}, \mathrm{mmol} / \mathrm{L}$ & 0.026 & 0.883 \\
\hline MCV, fL & 0.015 & 0.898 & $\mathrm{HCO}_{3}, \mathrm{mmol} / \mathrm{L}$ & -0.282 & $0.020 *$ \\
\hline MPV, fL & -0.098 & 0.405 & $\mathrm{CL}, \mathrm{mmol} / \mathrm{L}$ & 0.175 & 0.274 \\
\hline $\mathrm{HCT}, \mathrm{L} / \mathrm{L}$ & -0.198 & 0.148 & Crea, $\mathrm{mmol} / \mathrm{L}$ & -0.116 & 0.469 \\
\hline $\mathrm{PCT}, \mathrm{L} / \mathrm{L}$ & -0.011 & 0.930 & CYSC, mg/L & 0.248 & $0.046^{*}$ \\
\hline PDW, 10GSD & 0.158 & 0.189 & PH value & 0.113 & 0.523 \\
\hline RDW, \% & 0.171 & 0.166 & $\mathrm{~K}, \mathrm{mmol} / \mathrm{L}$ & 0.074 & 0.644 \\
\hline \multirow{2}{*}{$\begin{array}{c}\text { llation function } \\
\text { APTT, s }\end{array}$} & \multirow[b]{2}{*}{-0.241} & \multirow[b]{2}{*}{0.051} & Urea, mmol/L & -0.049 & 0.672 \\
\hline & & & Uric, mmol/L & 0.182 & 0.336 \\
\hline $\mathrm{PT}, \mathrm{s}$ & 0.03 & 0.811 & \multicolumn{3}{|l|}{ Serum lipid profile } \\
\hline PTA, \% & -0.258 & $0.037 *$ & ApoA1, mmol/L & L 0.117 & 0.623 \\
\hline INR & 0.251 & $0.042 *$ & ApoB, mmol/L & -0.117 & 0.623 \\
\hline D-Dimer, ug/m & 10.206 & 0.097 & FBG, $\mathrm{mmol} / \mathrm{L}$ & 0.654 & $<0.001^{* * *}$ \\
\hline \multicolumn{3}{|c|}{ lar injury-related parameters } & HDL-C, mmol/L & L 0.195 & 0.175 \\
\hline CK, U/L & -0.039 & 0.756 & $\mathrm{TC}, \mathrm{mmol} / \mathrm{L}$ & 0.063 & 0.678 \\
\hline $\mathrm{CKMB}, \mathrm{U} / \mathrm{L}$ & 0.213 & 0.198 & $\mathrm{TG}, \mathrm{mmol} / \mathrm{L}$ & -0.223 & 0.120 \\
\hline \multirow{2}{*}{$\begin{array}{l}\text { y response } \\
\text { CRP, mg/L }\end{array}$} & \multirow[b]{2}{*}{0.442} & \multirow{2}{*}{$0.001^{* * *}$} & $\mathrm{LDL}-\mathrm{C}, \mathrm{mmol} / \mathrm{L}$ & 0.026 & 0.859 \\
\hline & & & & & \\
\hline
\end{tabular}

Note, 
BMI, Body Mass Index; HR, heart rate; WBC, white blood cells; RBC, red blood cells; HGB, hemoglobin; PLT, Platelet; BA, basophil; EO, eosinophil; LY, lymphocyte; MO, monocyte; NE, neutrophil; MCH, mean corpuscular hemoglobin; MCHC, mean corpuscular hemoglobin concentration; MCV, mean corpuscular Volume; MPV, mean platelet volume; HCT, hematocrit; PCT, platelet hematocrit; PDW, platelet distribution width; RDW, red blood cell volume distribution width; APTT, activated partial thromboplastin time; PT, prothrombin time; PTA, prothrombin activity, INR, international normalized ratio; CK, creatine kinase; CKMB, creatine kinase isoenzyme MB; CRP, C-reactive protein; ALB, albumin; ALP, alkaline phosphatase; ALT, alanine aminotransferase; AST, aspartate aminotransferase; DBIL, direct dilirubin; TBIL, total bilirubin; CHE, cholinesterase; GGT, gamma glutamyl transpeptidase; TBA, total bile acid; TP, total protein; PA, pre-albumin; LDH, lactate dehydrogenase; Na, serum sodium; CL, serum chlorine; Crea, Creatinine; CYSC, Cystatin C; K, serum kalium; ApoA1, apolipoprotein A-1; ApoB, apolipoprotein B; FPG, fasting plasma glucose; HDL-C, high-density lipoprotein-cholesterol; TC, total cholesterol; TG, triglycerides; LDL-C, low-density lipoprotein-cholesterol.

$* \mathrm{P}<0.05 ; * * \mathrm{P}<0.01 ; * * * \mathrm{P}<0.001$

Table 5 Diagnostic value of SAA and its combinations with CRP and D-Dimer for AAD patients

\begin{tabular}{|c|c|c|c|c|c|c|}
\hline & AUC & $95 \% \mathrm{CI}$ & P-value & cut-off & Sensitivity (\%) & Specificity (\%) \\
\hline $\mathrm{AAD}$ & 0.942 & $0.902-0.981$ & $<0.001$ & 0.427 & 0.908 & 0.937 \\
\hline TAAD & 0.939 & $0.873-1.004$ & $<0.001$ & 0.427 & 0.919 & 0.937 \\
\hline TBAD & 0.937 & $0.883-0.990$ & $<0.001$ & 0.462 & 0.881 & 0.937 \\
\hline \multicolumn{7}{|l|}{ Combination } \\
\hline SAA+CRP & 0.977 & 0.955-0.999 & $<0.001$ & - & 0.944 & 0.938 \\
\hline SAA+D-Dimer & 0.9 & $0.838-0.963$ & $<0.001$ & - & 0.848 & 0.938 \\
\hline \multicolumn{7}{|l|}{ Death } \\
\hline SAA (death v.s. survival) & 0.732 & $0.612-0.853$ & 0.001 & 4.998 & 0.739 & 0.625 \\
\hline CRP (death v.s. survival) & 0.826 & $0.709-0.942$ & $<0.001$ & 82.55 & 0.789 & 0.771 \\
\hline D-Dimer (death v.s. survival) & 0.715 & $0.562-0.869$ & 0.006 & 1.945 & 0.7 & 0.739 \\
\hline NE\% (death v.s. survival) & 0.678 & $0.549-0.808$ & 0.017 & 72.976 & 0.857 & 0.491 \\
\hline
\end{tabular}


Table 6. Associations of parameters with the upper stratum of the SAA levels when compared with the lower stratum

\begin{tabular}{|c|c|c|c|c|c|c|c|}
\hline & \multirow[t]{2}{*}{ SAA lower } & SAA upper & \multirow[t]{2}{*}{$P$ value } & & \multirow[t]{2}{*}{ SAA lower } & SAA upper & \multirow[t]{2}{*}{$P$ value } \\
\hline & & OR $(95 \% \mathrm{Cl})$ & & & & OR $(95 \% \mathrm{Cl})$ & \\
\hline$r$ & 1 Reference & $0.98(0.92 ; 1.04)$ & 0.5343 & ALB, $g / L$ & 1 Reference & $0.94(0.84 ; 1.05)$ & 0.3035 \\
\hline ension, $\mathrm{n}$ & 1 Reference & $3.12(0.76 ; 12.84)$ & 0.1141 & ALP, U/L & 1 Reference & $1.01(0.99 ; 1.03)$ & 0.3828 \\
\hline $2 x, n$ & 1 Reference & $1.64(0.31 ; 8.54)$ & 0.5579 & $\mathrm{ALT}, \mathrm{U} / \mathrm{L}$ & 1 Reference & $1.01(0.99 ; 1.02)$ & 0.4522 \\
\hline $2 r, \mu g / m L$ & 1 Reference & $1.72(0.79 ; 3.75)$ & 0.1752 & AST, U/L & 1 Reference & $1.00(0.99 ; 1.02)$ & 0.5672 \\
\hline \multirow[t]{2}{*}{$\mathrm{Ig} / \mathrm{L}$} & 1 Reference & 1.05 (1.00; 1.09) & 0.0385 & $\mathrm{GGT}, \mathrm{U} / \mathrm{L}$ & 1 Reference & 1.00 (1.00; 1.01) & 0.5294 \\
\hline & 1 Reference & $1.49(0.17 ; 13.14)$ & 0.7188 & $\mathrm{DBIL}, \mu \mathrm{mol} / \mathrm{L}$ & 1 Reference & $1.77(0.71 ; 4.43)$ & 0.2232 \\
\hline $1, n$ & 1 Reference & $1.11(0.28 ; 4.50)$ & 0.8787 & TBIL, $\mu \mathrm{mol} / \mathrm{L}$ & 1 Reference & $1.02(0.94 ; 1.10)$ & 0.6170 \\
\hline$\times 10^{9} / \mathrm{L}$ & 1 Reference & $1.74(1.18 ; 2.56)$ & 0.0049 & $\mathrm{PA}, \mathrm{mg} / \mathrm{dL}$ & 1 Reference & $0.83(0.71 ; 0.96)$ & 0.0101 \\
\hline $10^{12} / \mathrm{L}$ & 1 Reference & $0.55(0.18 ; 1.66)$ & 0.2869 & $\mathrm{TP}, \mathrm{g} / \mathrm{L}$ & 1 Reference & $0.97(0.89 ; 1.05)$ & 0.3956 \\
\hline $1 / L$ & 1 Reference & $0.96(0.92 ; 1.00)$ & 0.0711 & TBA, $\mu \mathrm{mol} / \mathrm{L}$ & 1 Reference & $0.97(0.86 ; 1.10)$ & 0.6683 \\
\hline $10^{9} / \mathrm{L}$ & 1 Reference & $1.00(0.99 ; 1.01)$ & 0.9735 & $\mathrm{~K}, \mathrm{mmol} / \mathrm{L}$ & 1 Reference & $3.31(0.91 ; 12.06)$ & 0.0701 \\
\hline $\mathrm{Imol} / \mathrm{L}$ & 1 Reference & $1.17(0.80 ; 1.70)$ & 0.4191 & $\mathrm{CL}, \mathrm{mmol} / \mathrm{L}$ & 1 Reference & $0.98(0.81 ; 1.17)$ & 0.8006 \\
\hline $0^{9} / \mathrm{L}$ & 1 Reference & $0.18(0.03 ; 1.20)$ & 0.0764 & $\mathrm{Na}, \mathrm{mmol} / \mathrm{L}$ & 1 Reference & $0.95(0.86 ; 1.05)$ & 0.3128 \\
\hline$J^{9} / \mathrm{L}$ & 1 Reference & $0.79(0.01 ; 114.81)$ & 0.9253 & HDL-C, mmol/L & 1 Reference & $1.06(1.01 ; 1.10)$ & 0.0137 \\
\hline $19 / \mathrm{L}$ & 1 Reference & $0.85(0.77 ; 0.93)$ & 0.0004 & LDL-C, mmol/L & 1 Reference & $1.27(0.52 ; 3.11)$ & 0.6047 \\
\hline $0^{9} / \mathrm{L}$ & 1 Reference & $1.02(0.94 ; 1.10)$ & 0.7075 & $\mathrm{TC}, \mathrm{mmol} / \mathrm{L}$ & 1 Reference & $1.40(0.56 ; 3.52)$ & 0.4711 \\
\hline $0^{9} / \mathrm{L}$ & 1 Reference & $1.97(1.24 ; 3.11)$ & 0.0039 & $\mathrm{TG}, \mathrm{mmol} / \mathrm{L}$ & 1 Reference & $0.50(0.15 ; 1.60)$ & 0.2403 \\
\hline,$u / L$ & 1 Reference & $1.01(0.89 ; 1.15)$ & 0.8363 & Urea, mmol/L & 1 Reference & $1.17(0.87 ; 1.55)$ & 0.2950 \\
\hline $\mathrm{Jg}$ & 1 Reference & $0.83(0.56 ; 1.21)$ & 0.3320 & Uric, mmol/L & 1 Reference & $1.01(0.98 ; 1.05)$ & 0.3890 \\
\hline$g / \mathrm{L}$ & 1 Reference & $0.97(0.91 ; 1.04)$ & 0.4322 & Crea, $\mathrm{mmol} / \mathrm{L}$ & 1 Reference & $1.09(0.97 ; 1.23)$ & 0.1325 \\
\hline L & 1 Reference & $0.95(0.84 ; 1.08)$ & 0.4593 & $\mathrm{C} 1 \mathrm{q}, \mathrm{mmol} / \mathrm{L}$ & 1 Reference & $1.03(0.98 ; 1.08)$ & 0.2637 \\
\hline $\mathrm{L}$ & 1 Reference & $0.77(0.47 ; 1.27)$ & 0.3056 & $\mathrm{HCO}_{3}, \mathrm{mmol} / \mathrm{L}$ & 1 Reference & $0.77(0.57 ; 1.04)$ & 0.0860 \\
\hline$/ \mathrm{L}$ & 1 Reference & $0.51(0.01 ; 3.93)$ & 0.9060 & $\mathrm{PH}$ value & 1 Reference & $0.08(0 ; 921.56)$ & 0.5964 \\
\hline OGSD & 1 Reference & $1.03(0.80 ; 1.32)$ & 0.8293 & APTT, s & 1 Reference & $0.90(0.80 ; 1.01)$ & 0.0789 \\
\hline 。 & 1 Reference & $2.43(0.99 ; 5.97)$ & 0.0535 & PT, s & 1 Reference & $1.08(0.71 ; 1.64)$ & 0.7235 \\
\hline $1 / L$ & 1 Reference & $1.01(1.00 ; 1.02)$ & 0.0634 & PTA, s & 1 Reference & $0.96(0.90 ; 1.02)$ & 0.1644 \\
\hline
\end{tabular}

Note,

HR, heart rate; WBC, white blood cells; RBC, red blood cells; HGB, hemoglobin; PLT, Platelet; BA, basophil; EO, eosinophil; LY, lymphocyte; MO, monocyte; $\mathrm{NE}$, neutrophil; $\mathrm{MCH}$, mean corpuscular hemoglobin; $\mathrm{MCHC}$, mean corpuscular hemoglobin concentration; MCV, mean corpuscular Volume; MPV, mean platelet volume; HCT, hematocrit; PCT, platelet hematocrit; PDW, platelet distribution width; RDW, red blood cell volume distribution width; APTT, activated partial thromboplastin time; PT, prothrombin time; PTA, prothrombin activity; CKMB, creatine kinase isoenzyme MB; CRP, C-reactive protein; ALB, albumin; ALP, alkaline phosphatase; ALT, alanine aminotransferase; AST, aspartate aminotransferase; DBIL, direct dilirubin; TBIL, total bilirubin; $\mathrm{CHE}$, cholinesterase; GGT, gamma glutamyl transpeptidase; TBA, total bile acid; TP, total protein; PA, pre-albumin; LDH, lactate dehydrogenase; $\mathrm{Na}$, serum sodium; CL, serum chlorine; Crea, Creatinine; CYSC, Cystatin C; $\mathrm{K}$, serum kalium; ApoA1, apolipoprotein A-1; ApoB, apolipoprotein B; FPG, fasting plasma glucose; HDL-C, high-density lipoprotein-cholesterol; TC, total cholesterol; TG, triglycerides; LDL-C, low-density lipoprotein-cholesterol. 
Table 7 Univariate and multivariate logistic regression analyses for in-hospital mortality

\begin{tabular}{lcccc}
\hline & \multicolumn{1}{c}{ Model 1} & & Model 2 \\
\hline & OR $(95 \% \mathrm{CI})$ & P-value & OR $(95 \%$ CI $)$ & P-value \\
\hline Type of AAD & $0.47(0.16 ; 1.32)$ & 0.152 & $0.48(0.17 ; 1.36)$ & 0.167 \\
\hline HR, bmp & $1.01(0.97 ; 1.05)$ & 0.584 & $1.01(0.97 ; 1.05)$ & 0.536 \\
\hline Hypertension, $\%$ & $1.22(0.41 ; 3.64)$ & 0.724 & $1.13(0.37 ; 3.40)$ & 0.832 \\
\hline Smoker, $\%$ & $0.63(0.20 ; 1.96)$ & 0.421 & $0.63(0.20 ; 2.00)$ & 0.432 \\
\hline $\mathrm{D}-\mathrm{Dimer}, \mu \mathrm{g} / \mathrm{mL}$ & $1.19(0.98 ; 1.43)$ & 0.074 & $1.20(0.99 ; 1.46)$ & 0.065 \\
$\mathrm{CRP}, \mathrm{mg} / \mathrm{L}$ & $1.02(1.01 ; 1.03)$ & 0.000 & $1.03(1.01 ; 1.04)$ & 0.000 \\
$\mathrm{WBC}, \times 10^{9} / \mathrm{L}$ & $1.17(1.03 ; 1.32)$ & 0.013 & $1.17(1.03 ; 1.33)$ & 0.015 \\
\hline $\mathrm{EO}, \times 10^{9} / \mathrm{L}$ & $0.68(0.40 ; 1.15)$ & 0.148 & $0.68(0.40 ; 1.16)$ & 0.161 \\
$\mathrm{LY}, \times 10^{9} / \mathrm{L}$ & $0.92(0.85 ; 0.99)$ & 0.030 & $0.92(0.85 ; 0.99)$ & 0.031 \\
\hline $\mathrm{NE}, \times 10^{9} / \mathrm{L}$ & $1.05(1.00 ; 1.11)$ & 0.040 & $1.06(1.00 ; 1.11)$ & 0.041 \\
$\mathrm{HCO}, \mathrm{mmol} / \mathrm{L}$ & $0.69(0.53 ; 0.89)$ & 0.004 & $0.67(0.51 ; 0.88)$ & 0.004 \\
\hline $\mathrm{LDH}, \mathrm{U} / \mathrm{L}$ & $1.00(0.99 ; 1.00)$ & 0.097 & $1.00(0.99 ; 1.00)$ & 0.151 \\
\hline $\mathrm{FPG}, \mathrm{mmol} / \mathrm{L}$ & $1.17(0.95 ; 1.44)$ & 0.133 & $1.16(0.95 ; 1.43)$ & 0.149 \\
\hline $\mathrm{SAA}, \mu \mathrm{g} / \mathrm{dL}$ & $1.22(1.05 ; 1.42)$ & 0.011 & $1.25(1.07 ; 1.47)$ & 0.005 \\
\hline $\mathrm{NOte}$ & & &
\end{tabular}

Note,

$\mathrm{AAD}$, acute aortic dissection; HR, heart rate; CRP, C reactive protein; WBC, white blood cell; EO, eosinophil; LY, lymphocyte; NE, neutrophil; LDH, lactate dehydrogenase; FPG, fasting plasma glucose; SAA, serum amyloid A, CI: confidence interval, Model 1: no adjustments, Model 2: adjusted for age, gender, BMI

\section{Figures}




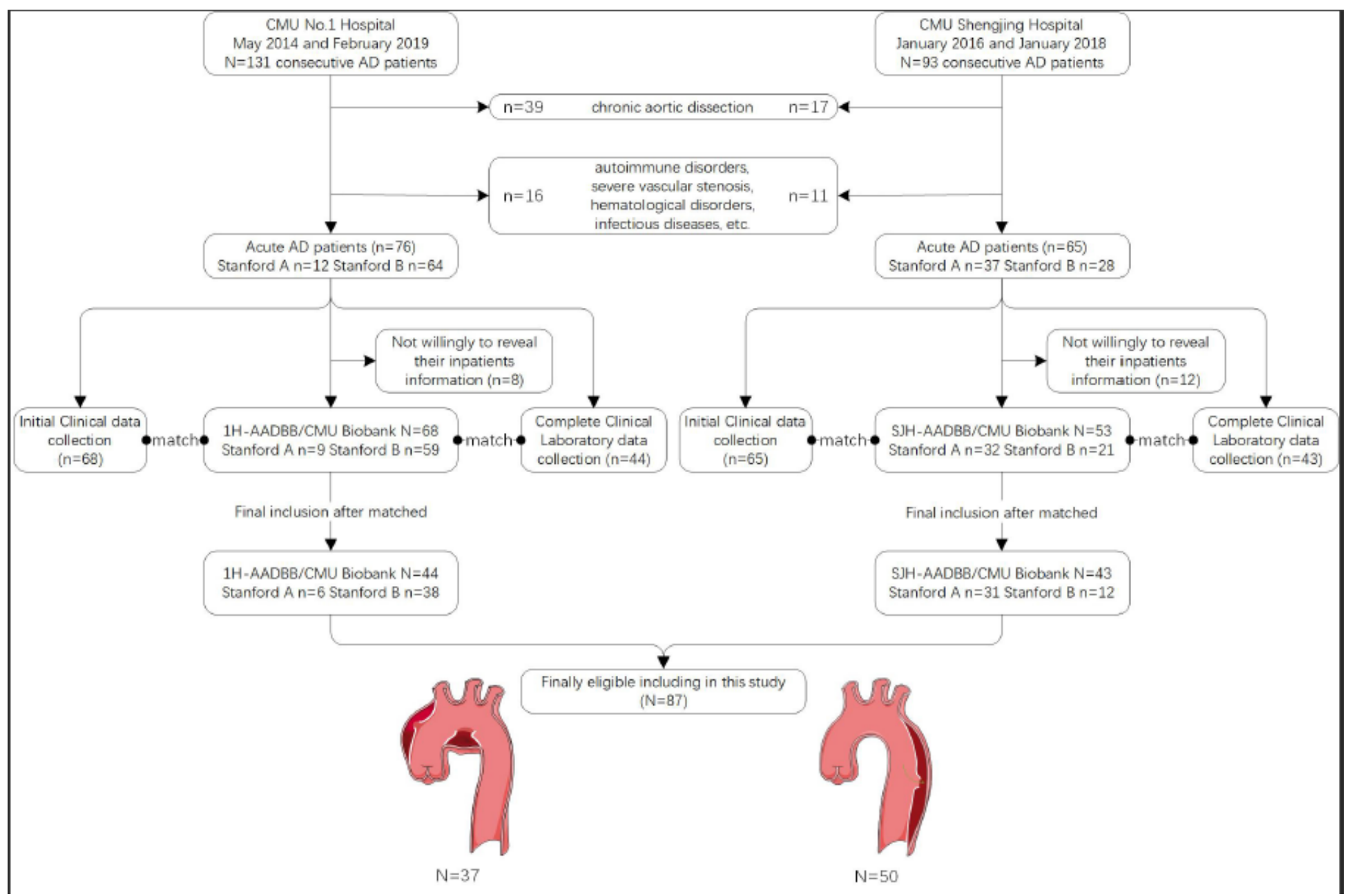

Figure 1

Flowchart of AAD patients selection and blood sample recovered from the First Hospital of CMU Aortic Dissection Blood sample Biobank (1H-ADBB/CMU) and Shengjing Hospital of CMU Aortic Dissection Blood sample Biobank (SJH-ADBB/CMU). 
A

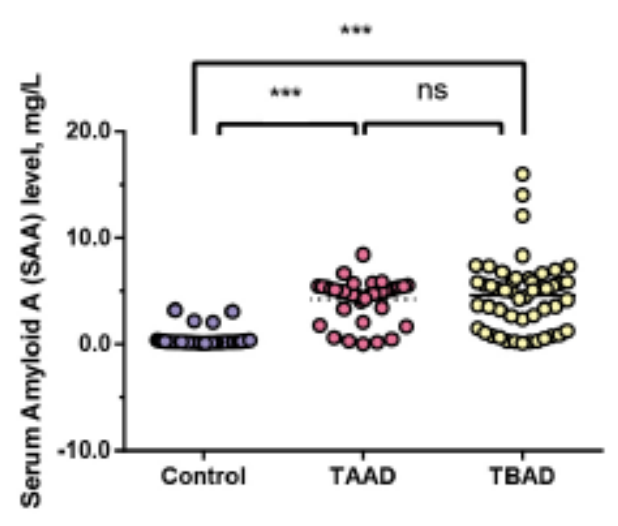

C

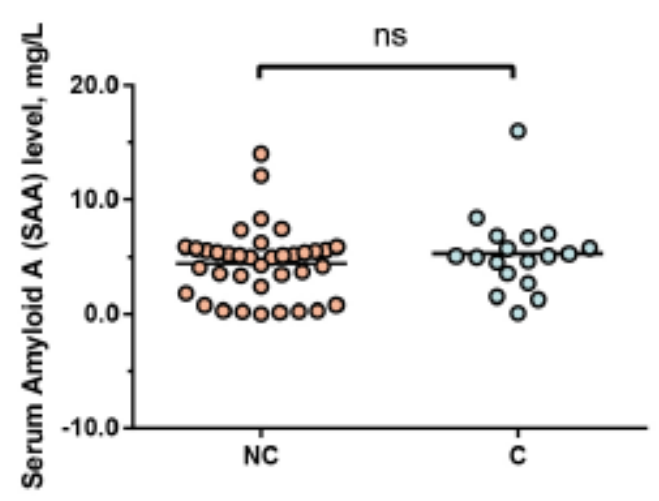

B

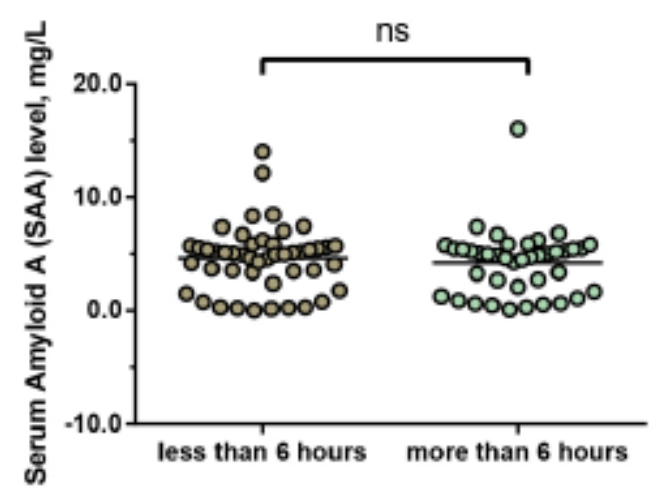

D

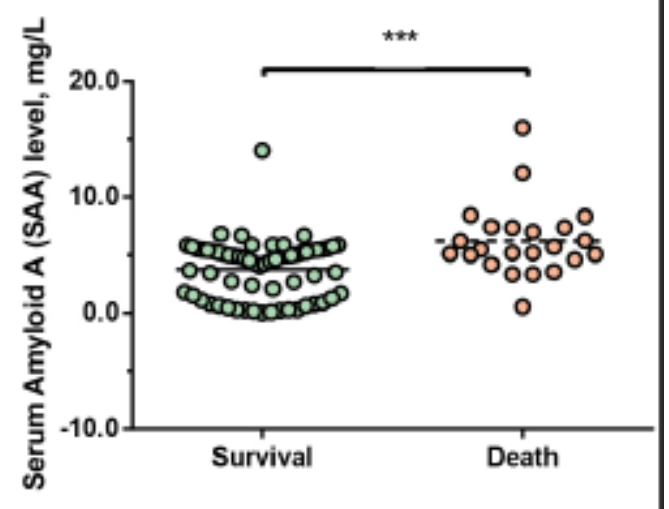

Figure 2

Analysis of SAA levels in different groups. (A) Comparison of SAA levels among controls, TAAD and TBAD. And sub-group analysis of SAA levels in AAD patients: (B)comparison of SAA levels between AAD with high-risk pain features that persisted less than six hours and more than six hours, and (C)comparison of SAA levels between AAD with communicating and non-communicating false lumen (C and NC), and (D) comparison of SAA levels between death cases and survival cases. ${ }^{*} P<0.05, * \star P<$ $0.01,{ }^{\star}{ }^{*} \mathrm{P}<0.001$, ns, no significance. 
A

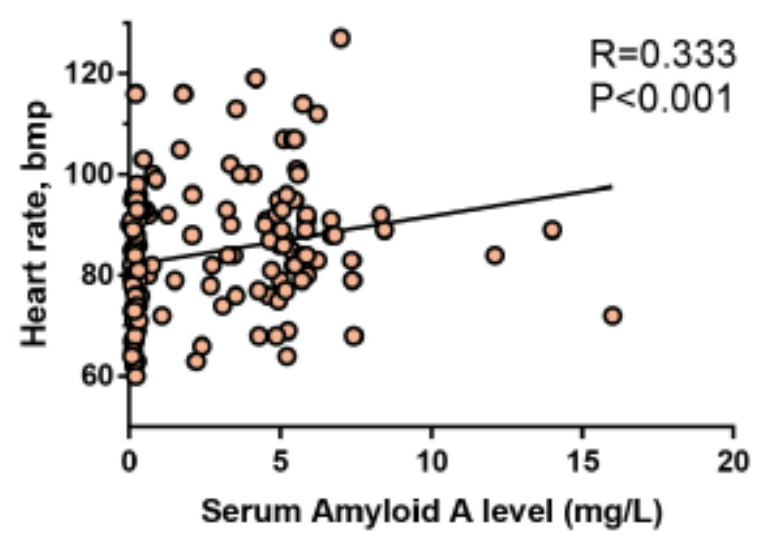

C

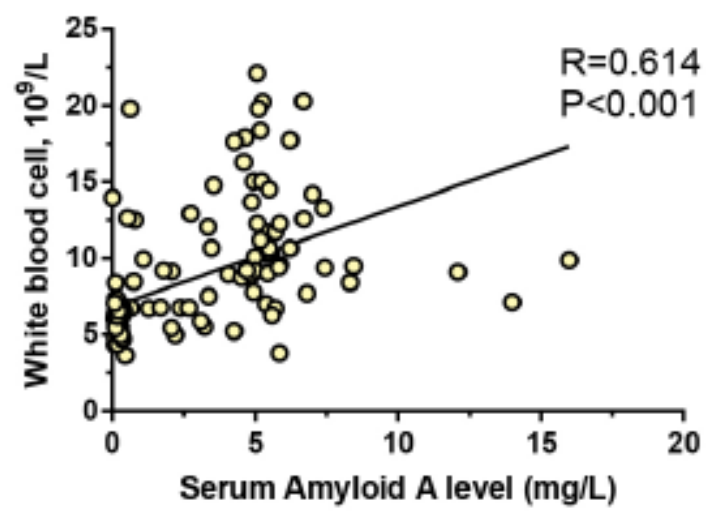

B

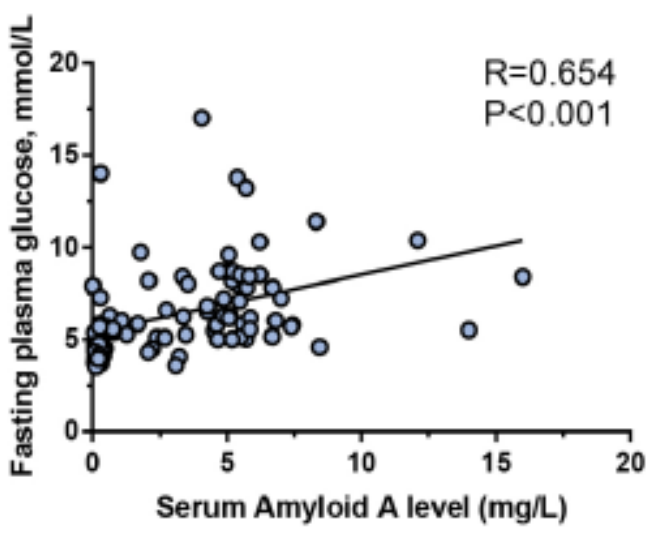

D

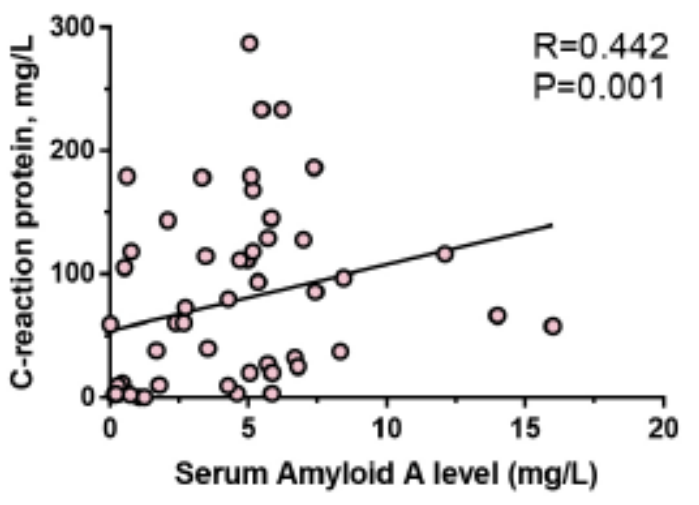

Figure 3

Correlations between SAA levels and clinical features in AAD patients. The horizontal axis represents SAA levels in $\mathrm{mg} / \mathrm{L}$ and the vertical axis represents (A)heart rate, bmp, (B)Fast plasma glucose, $\mathrm{mmol} / \mathrm{L}$, (C)white blood cell, 109/L, and (D)C-reactive protein, $\mathrm{mg} / \mathrm{L}$. 


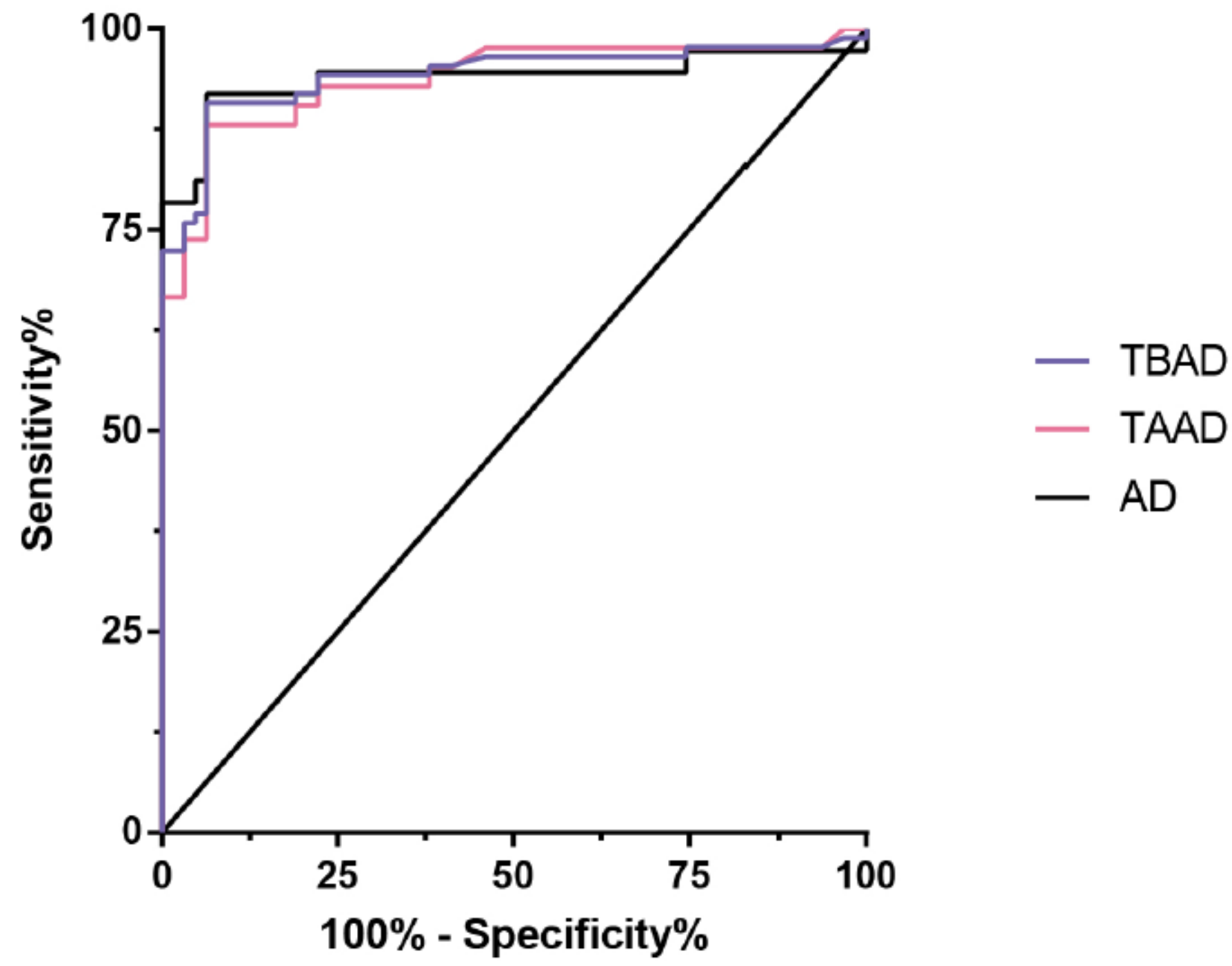

Figure 4

ROC analysis of SAA levels for the evaluation of TAAD, TBAD, and AAD. The vertical axis represents the sensitivity and the horizontal axis represents the 1-specificity 